\title{
Spare Tire? \\ Stock Markets, Banking Crises, and Economic Recoveries
}

\author{
Ross Levine, Chen Lin and Wensi Xie*
}

June 2015

\begin{abstract}
Do stock markets act as a "spare tire" during banking crises, providing an alternative corporate financing channel and mitigating the economic severity of crises? Using firm-level data in 36 countries from 1990 through 2011, we find that the adverse consequences of banking crises on equity issuances, firm profitability, employment, and investment efficiency are smaller in countries with stronger shareholder protection laws. These findings are not explained by the development of stock markets or financial institutions prior to the crises, the severity of the banking crisis, or overall economic, legal, and institutional development.
\end{abstract}

JEL Codes: G32; G21; K22; D21.

Key words: Shareholder protection laws; Corporate finance; Financial Crises; Firm profits; Firm investment choices.

* Levine: Haas School of Business at University of California, Berkeley, Milken Institute, and NBER. Email: rosslevine@berkeley.edu. Lin: Faculty of Business and Economics, the University of Hong Kong, Hong Kong. Email: chenlin1@hku.hk. Xie: Faculty of Business and Economics, the University of Hong Kong, Hong Kong. Email: wencyxie@hku.hk. We thank Franklin Allen, Thorsten Beck, Daniel Berkowitz, David Chor, Craig Doidge, Erik Gilje, Itay Goldstein, Todd Gormley, Gary Gorton, Jun-Koo Kang, Florencio Lopez-de-Silanes, Michelle Lowry, Yona Rubinstein, Luke Taylor, Sheridan Titman, Annette Vissing-Jorgensen, Luigi Zingales, an anonymous referee, and seminar participants at the 2015 Asian Bureau of Finance and Economic Research Conference and the University of California, Berkeley for helpful comments and discussions. Lin gratefully acknowledges the financial support from the Research Grants Council of Hong Kong (Project No. 448412 and T31/717/12R). 


\section{Introduction}

Researchers show that shareholder protection laws shape the functioning of stock markets and the efficiency of corporate investments. By reducing the ability of corporate insiders to expropriate resources from minority shareholders, stronger shareholder protection laws boost stock market development (La Porta et al., 1997, 1998), the dispersion of ownership (La Porta et al., 1999), market valuations (La Porta et al., 2002), stock market liquidity (Beck et al., 2003; Brockman and Chung, 2003), the information content of stock prices (Morck et al., 2000), and the efficiency of corporate investments (Demirguc-Kunt and Maksimovic, 1998; McLean et al., 2012), with potentially large ramifications on economic growth (Levine and Zervos, 1998).

Researchers have not, however, assessed whether shareholder protection laws influence how firms respond to banking crises. When banking systems fail, this disrupts the flow of bank credit to firms with harmful effects on investment, employment, and economic growth (e.g., Kroszner et al., 2007, and Reinhart and Rogoff, 2009). In 1999, Alan Greenspan, then Chairman of the Federal Reserve System, argues that stock markets could mitigate these negative effects. Using the analogy of a "spare tire," he conjectures that banking crises in Japan and East Asia would have been less severe if those countries had built the necessary legal infrastructure, so that their stock markets could have provided financing to corporations when their banking systems could not. If firms can substitute equity issuances for bank loans during banking crises, then banking crises will have less harmful effects on firms and the economy. Although official entities and others discuss the spare tire argument (e.g., U.S. Financial Crisis Inquiry Commission, 2011; Wessel, 2009), we are unaware of systematic assessments of this view.

In this paper, we evaluate several interrelated implications of the spare tire view. First the spare tire view stresses that if firms can issue equity at low cost when banking crises limit the 
flow of bank loans to firms, this will ameliorate the impact of the banking crisis on firm performance. Put differently, if a banking crisis shuts off bank lending and firms do not have an alternative source of financing, firms will suffer more than they would in the presence of a stock market that provides an alternative source of external finance. Second, the benefits of stock markets when banks reduce lending accrue primarily to firms that depend heavily on external finance. For those firms that do not rely on external finance, there are likely to be fewer benefits from having substitute forms of external finance. Third, the spare tire view stresses the ability of the stock market to provide financing during a banking crisis, not the size of the market before the crisis. Although bank loans might be the preferred source of external financing during normal time, the spare tire view holds that when this preferred source goes "flat," equity issuances can, at least partially, substitute for bank loans. Critically, for the stock market to play this role, the legal infrastructure must be in place before the banking crisis, so that the market can respond when the banking system falters. It is the pre-crisis legal infrastructure-not necessarily the precrisis size of the stock market— that allows the market to act as a spare tire in times of crisis.

We assess these predictions by combining several datasets and employing a differencein-differences methodology. The dependent variable is a measure of equity issuances, firm profitability, employment, or investment. We obtain these, and other, firm-level data from the Worldscope database. The key explanatory variable is the interaction term of (1) a measure of the strength of shareholder protection laws and (2) a systemic banking crisis dummy variable that equals one in the year of the onset of the crisis and remains one for the next three years. To measure the strength of shareholder protection laws, we use the Djankov et al. (2008) “Anti-selfdealing” index, which gauges the degree to which the law protects minority shareholders from being expropriated by managers or controlling shareholders using self-dealing transactions. 
Based on an extensive body of research, we interpret greater values of the Anti-self-dealing index as indicating that outside investors will feel more confident about buying shares in companies and this will improve the firms' accessibility to equity market financing. To date systemic banking crisis, we use Laeven and Valencia (2012). If the key interaction term enters positively in the equity issuance, performance, and employment regressions, then this would suggest that equity issuances, firm performance, and employment deteriorate less following a systemic crisis when the country has stronger shareholder protection laws. The regressions also include an assortment of time-varying country and firm characteristics, as well as firm and year fixed effects. Our main sample includes about 3,600 firms, in 36 countries, over the period from 1990 through 2011.

We also test whether the particular firms that the spare tire view predicts will benefit most from stronger shareholder protections actually do benefit most. The spare tire view stresses that firms that rely heavily on external finance will benefit more from the spare tire financing mechanisms fostered by stronger shareholder protection laws than other firms. Put differently, if some firms do not use bank financing, then having a replacement source of external finance will not matter much for their performance. We therefore test whether firms in financially dependent industries, as defined by Rajan and Zingales (1998), benefit more from stronger shareholder protection laws during a banking crisis than other firms.

The findings are consistent with the predictions of the spare tire view. In particular, following a systemic banking crisis, stronger shareholder protection laws facilitate equity financing by firms in financially dependent industries. That is, among firms in financially dependent industries, equity financing falls by less following the onset of a systemic banking crisis in economies with higher values of the Anti-self-dealing index than in economies with 
weaker shareholder protection laws. Also consistent with the spare tire view, we find that firms in economies with stronger shareholder protection laws experience less pronounced declines in profits and employment after the start of a banking crisis and the mitigating effects of shareholder protection laws are especially large among firms in financially dependent industries. Although systemic crises are associated with a drop in firm earnings and employment, the drop is much less severe in economies with large values of the Anti-self-dealing index. This is consistent with the argument that the pre-crisis legal infrastructure shapes an economy's response to crises.

The estimated economic effects are large. Consider two countries, one that has the sample average value of the Anti-self-dealing index and the other that has a one standard deviation larger Anti-self-dealing index. If both countries have average values of the other country characteristics, our estimates indicate that in response to a banking crisis, firms in the stronger Anti-self-dealing country will experience a 36\% smaller drop in profitability than firms in the country with comparatively weak shareholder protection laws. Furthermore, in high financial dependent industries, the estimates suggest that firms in the stronger Anti-self-dealing country will raise $82 \%$ more funds through new equity issuances than those in the country with average shareholder protection laws.

These results reflect shareholder protection laws in particular, and not stock market development prior to the crisis, the size of the banking crisis, the level of financial institution development, or the levels of economic, legal, and institutional development. The core analyses control for the interaction terms between the crisis dummy variable and (a) stock market capitalization prior to the crisis, (b) credit contraction during the crisis, (c) GDP per capita, and (d) the size of the financial intermediary sector. Additionally, robustness tests include interaction terms between the crisis dummy variable and the rule of law, an overall index of the degree to 
which legal and other institutions effectively promote the protection of property rights, the legal rights of creditors, the rule of law, political stability, the ability of the public to choose public officials and hold those officials accountable, government effectiveness, regulatory quality, and control of official corruption. When controlling for all of these interaction terms, we continue to find that the interaction term between the Anti-self-dealing index and the systemic crisis dummy variable enters the firm equity financing and performance regressions positively and significantly. These results are consistent with the view that the pre-crisis strength of shareholder protection laws per se boosts the financing and performance of firms following banking crises. In sum, these findings support the spare tire view: economies do not necessarily use the spare tire during normal times, but when banking crises hit, having the right legal infrastructure in place allows the stock market to mitigate the effects of the crisis on firm performance and unemployment.

We consider several extensions. First, the spare tire view suggests that strong Anti-selfdealing rights can mitigate the effects of systemic banking crises on the efficiency of corporate investment. When crises shutdown the bank lending channel, this can tighten financing constraints and force firms to forgo efficient investments. If an alternative financing channel is available, however, firms will substitute out of bank finance and into this alternative, reducing the adverse effects of crises on firm investment efficiency. We test whether economies with stronger shareholder protection laws experience a smaller deterioration in corporate investment efficiency following banking crises than economies with weaker such laws.

We find that in economies with stronger Anti-self-dealing laws, firm investment efficiency falls less in response to a banking crisis than in other economies. To measure investment efficiency, we use the sensitivity of real capital expenditures to investment opportunities, as measured by Tobin’s Q. During systemic banking crises, we find that real 
investment sensitivity to Q falls by less in economies with stronger shareholder protection laws than in economies with weaker such laws.

Second, we extend the work on firm employment by considering the role of labor regulations. We assess whether the relationship between firm employment and shareholder protection laws varies with the degree of labor market rigidity, as measured by the regulatoryinduced cost of firing workers measure constructed by Botero et al. (2004). If the costs of firing workers are a large impediment to firms changing their labor forces, then other factorsincluding the availability of external finance-will have less of an impact on firm employment in a banking crisis. From this perspective, it is only when the costs of firing workers are not too high that shareholder protections laws can materially mitigate the employment effects of a crisis. Our results confirm this view: When the costs of firing workers are not especially high, firm employment falls much less during systemic banking crises when the economy has stronger Anti-self-dealing laws. However, strong Anti-self-dealing laws do not have the same mitigating effects on the drop in employment when labor regulations make it very expensive to fire workers.

Third, we examine whether shareholder protection laws influence the degree to which banks raise equity financing following the onset of a systemic banking crisis. The core empirical results discussed above are for manufacturing firms, but the spare tire view might apply to banks as well. For example if bank assets fall in value, raising equity financing will allow banks to sustain their lending operations. Thus, shareholder protection laws could influence how banks respond to a crisis by making it easier for them to raise equity during crises. This is what we find. Following a crisis, banks in economies with higher values of the Anti-self-dealing index raise more equity financing than those in economies with weaker such shareholder protections laws. 
Fourth, we assess dividend payments. The "agency” view of dividend payout policy stressed by La Porta et al. (2000) implies that shareholders will be more willing to allow firms to postpone dividend payouts when an economy has strong shareholder protection laws. From this perspective, firms operating in economies with stronger shareholder protections might reduce dividend payments more and retain a larger proportion of earnings for working capital or investments with beneficial effects on economic performance during a banking crisis. We find no evidence for this mechanism. During a crisis, dividend payments do not vary systematically with the Anti-self-dealing index.

A major concern with our investigation is that shareholder protection laws might influence the severity of banking crises, not the ability of firms to recover from crises. Several observations, however, suggest that our results do not reflect the impact of shareholder protection laws on crises. First, we show that shareholder protection laws do not account for cross-country differences in the severity of banking crises, as measured by the reduction of bank credit. Second, all of the results in the paper hold when controlling for the size of the crisis. Third, we find that shareholder protections are strongly associated with firm performance, employment, and investment efficiency after systematic banking crises even when controlling for the size of banks and stock markets, the overall level of legal and institutional development, and for many other features that could account for differences in the size, severity, and enduring effects of such crises. Finally, we show that following the onset of a crisis, stronger shareholder protections are associated with greater equity financing than in economies with weaker such laws. Thus, regardless of the size of the crisis, firms tend to increase equity issuances more when stronger shareholder protection laws provide a spare tire financing mechanism. Taken together, our research findings are consistent with the "spare tire” view: when strong shareholder 
protection laws provide the basis for stock markets to act as alternative sources of external financing during systemic banking crises, this tends to reduce the economic severity of the crisis and expedite the economic recovery.

Our findings relate to research on finance and employment. Pagano and Volpin (2008) and Beck et al. (2010) stress that well-developed financial systems encourage employment growth, and Chodorow-Reich (2014) shows that the deterioration of a bank has adverse effects on employment by its client firms. However, deeper financial systems might increase employment risk and volatility by forcing inefficient firms to shut down or restructure (Atanassov and Kim, 2009). We focus on a narrower question: Does the ability to access stock markets in times of banking distress mitigate the adverse impact of banking crises on employment? Our analyses provide an affirmative answer. When the costs of firing workers are not very high, economies with stronger shareholder protection laws experience a much smaller reduction in employment following banking crises.

The rest of the paper proceeds as follows. Section 2 describes the data, variables, and empirical methodology. Sections 3 and 4 present the empirical findings. Section 5 concludes. 


\section{Data, Variables, and Empirical Methodology}

\subsection{Sample}

We include a country and its firms in our analyses if the following criteria are satisfied. First, the country must be one of the 72 countries for which Djankov et al. (2008) provide information on shareholder protection laws. Second, the country must experience at least one systemic banking crisis over the 1990-2011 period, as defined in Laeven and Valencia’s (2012) database on systemic banking crises. Third, the Worldscope database by Thomson Reuters must provide complete financial data on at least three of a country's firms during the seven-year window centered on the start-year of the crisis, $[t-3, t+3]$, where $t$ is the start-year of the banking crisis according to Laeven and Valencia (2012). Finally, we exclude the United States because we use it as the benchmark country for defining industries by the degree to which they depend on external finance. All of the paper's conclusions however, are robust to including U.S. firms. Thus, assuming a balanced sample during the seven-year window around a crisis, we have seven times the number of firms in the crisis country firm-year observations for each crisis.

Based on these criteria, we compile data on over 3,600 firms across 36 countries during the period from 1990 through 2011. We primarily use data on publicly listed manufacturing companies with the U.S. standard industrial classification (SIC) code between 2000-3999. We start in 1990 because of data availability in Worldscope. Except as indicated below, all of the firm-level data are from Worldscope. In total, we have over 23,000 firm-year observations. When examining equity financing, we augment this sample of manufacturing firms and separately consider banks. Following the same selection criteria noted above, we collect data on 279 banks. We define those firms with the U.S. standard industrial classification (SIC) code equal to $6020-6029,6035,6036,6081,6082,6111,6141,6153,6159$, or 6712 as in the banking 
sector, which covers commercial banks, savings banks, credit institutions, and bank holding companies. 240 out of 279 are commercial banks with SIC code between 6020-6029.

\subsection{Shareholder protections measure}

The Djankov et al. (2008) Anti-self-dealing index measures the degree to which minority shareholders are protected from large shareholders engaging in self-dealing transactions that benefit the large shareholders at the expense of the small ones. The Anti-self-dealing index is constructed to measure the hurdles impeding a controlling shareholder from engaging in selfdealing transactions.

They construct the Anti-self-dealing index by surveying attorneys from Lex Mundi, which is an association of international law firms. The survey includes questions about a hypothetical self-dealing transaction between two companies called "Buyer" and "Seller.” In the stylized transaction, Mr. James owns $90 \%$ of Seller and 60\% of Buyer. Mr. James proposes that Buyer purchase trucks from Seller. Mr. James can benefit personally by having Buyer overpay Seller given his unequal ownership. The Anti-self-dealing index represents the hurdles that James must overcome to complete such a transaction. The index is composed of ex ante and ex post hurdles. The ex ante hurdles include the degree to which the transactions requires (1) approval by disinterested shareholders, (2) disclosure of the details of the transaction, (3) disclosure of the precise nature of Mr. James's relationships with the companies, and (4) an independent evaluation (e.g., by a financial expert or an independent auditor). The ex post impediments to self-dealing include: (1) whether disclosure in periodic filings (such as annual reports) is required, (2) whether a $10 \%$ shareholder can sue Mr. James or other corporate decision makers if the transaction loses money, (3) the ease of holding Mr. James or other 
authorities legally liable for civil damages, and (4) the ease with which potential plaintiffs can acquire evidence from the firms. The index ranges from zero to one, with higher value indicating stronger legal protections of minority shareholders. Appendix Table A.2 shows that Ukraine and Mexico have weak shareholder protection laws, while Malaysia and the United Kingdom have strong ones. In our sample of countries, the index has an average value of 0.44 , with a standard deviation of 0.21 .

\subsection{Banking-crisis event window}

Laeven and Valencia (2012) provide information on the start year of each systemic banking crisis during the period from 1970 through 2011. The start year of a 'systemic' banking crisis is defined as the first year when there are significant signs of financial distress in the banking sector including bank runs, a general realization that systemically important financial institutions are in trouble, bank liquidations, or significant policy interventions to assist or intervene in the banking system. Laeven and Valencia (2012) focus on systemic crises that disrupt the entire banking system, not just isolated institutions.

Appendix Table A.2 lists the start year of each crisis for the 36 countries in our sample. It shows that 21 crises coincide with the 2008 global financial crisis, and that six crises overlap with the 1997 Asian financial crisis. Over this period, 35 countries had one systemic banking crisis with the requisite firm-level data in Worldscope. Argentina had two banking crises, one in 1995 and the other in 2001. Since the $t+3$ date for the first Argentine crisis of our sample is 1998 and the t-3 date of the second crisis is also 1998, we define the pre-crisis period for both crises as 1992-1994. Then, for the first crisis, the post crisis period for the first Argentine crisis is 19951998, and the post crisis period for the second one is 2001-2004. We obtain the same results if 
we omit Argentina or treat the two crises as completely independent, so that the end year of the first crisis is part of the pre-crisis period of the second Argentine crisis.

\subsection{Equity financing and dividends}

We consider two measures of external equity finance. The first measure, Equity issuance, equals the change in the book value of common equity plus the change in deferred taxes minus the change in retained earnings during a specific year $t$, all scaled by total assets at the close of year t-1. Equity issuance was proposed by Baker et al. (2003) and is derived from corporate balance sheets. Equity issuance appropriately measures most equity transactions. For example, if a firm sells common shares in either a public or private seasoned equity offering (SEO), the book value of common equity will rise and the Equity issuance variable will appropriately measure this equity financing transaction. As another example, consider a firm that does not issue new equity but that makes a cash dividend payout. Equity issuance will correctly measure this activity as involving zero equity financing, since both the book value of common equity and retained earnings will fall. However, the Equity issuance variable does not precisely record transactions involving stock dividend payments since it is not a direct measure of the sale of shares, and there are differences in accounting practices across countries.

The second measure, Proceeds of IPO/SEO, equals the proceeds from public equity offerings, including both Initial Public Offerings (IPOs) and Seasoned Equity Offerings (SEOs), during year $t$ as a share of total assets at the close of year $t-1$. Proceeds of IPO/SEO is a direct, transaction-based measure of funds raised through the issuance of equity. The data are from the Securities Data Company's (SDC) Global New Issues database provided by Thomson Reuters. We use the common firm identifiers (Stock Exchange Daily Official List (SEDOL), 
(International Securities Identification Number (ISIN), and Firm Name) in both the SDC and Worldscope databases to match the issuing data with other firm-level data. Although the Proceeds of IPO/SEO is conceptually cleaner than the Equity issuance, the SDC database is less complete in its coverage of firms than the Worldscope database. For Proceeds of IPO/SEO, we have data on 1487 manufacturing firms with 9393 observations covered in both Worldscope and SDC. We also obtain Proceeds of IPO/SEO for 279 banks with 1763 observations to assess equity issuances by banks.

Dividend equals total cash dividends paid to common and preferred shareholders. We use Dividend to examine changes in the dividend payout decisions of firms in response to a systemic banking crisis. Based on past research, we scale Dividend by four different firm traits. We calculate Dividend yield as the ratio of dividends in year t to the market capitalization using the closing stock price at the end of year t-1 (Becker et al., 2011). Following Pinkowitz et al. (2006), Dividend to assets equals to dividends paid during year $\mathrm{t}$ divided by total assets at the close of year t-1. As in La Porta et al. (2000), Dividend to cash flow equals to dividends paid over year t divided by cash flow over the same year, and Dividend to sales equals to the ratio of dividends to net sales. We require the four denominators to be positive so that the dividend ratios are economically meaningful.

Appendix Table A.1 and Table 1 provide variable definitions and summary statistics. Of the 1487 manufacturing companies with data on Proceeds of IPO/SEO, 43\% issued new equity at least once during the crisis window, i.e., between period $t-3$ and $t+3$. The issuers tend to be the larger firms, accounting for almost $64 \%$ of the book value of assets of the sample of firms. Among the issuers, most issue equity only in one or two years of the seven years between $t$ - 3 and $t+3$, so that $75 \%$ of the total sample of firm-year observations has a value of zero for Proceeds of 
IPO/SEO. Specifically, among the 632 issuers, there are 930 equity transactions. There is notable heterogeneity in equity issuances. Proceeds of IPO/SEO ranges from 0 to 1.3 with a sample mean of 0.024 and a standard deviation of 0.13 . There is also substantial variation in dividend payouts. For example, Dividend to assets ranges from 0 to 0.16 with a sample mean of 0.014 and a standard deviation of 0.024 .

\subsection{Firm profitability, employment, and investment efficiency}

We use three indicators of firm profitability. Net income to assets equals net earnings minus dividends during a specific year $t$ as a share of total assets at the close of year t-1, where net earnings are defined as earnings after interest and taxes. To abstract from short-run fluctuations in interest and tax expenditures, we also examine EBIT to assets, which equals net earnings before interest and taxes during year t divided by total assets at the close of year t-1. To reduce the effects of potential earnings management on our measurement of firm performance, we also use Cash flow to assets, which equals net earnings after dividends in year t plus depreciation and amortization divided by total assets at the close of year t-1.

Firm employment equals the natural logarithm of the total number of employees and is measured in thousands of employees. Thus, a firm with 1000 workers will have a Firm employment value of 0 . If we scale the total number of employees by firm assets, the analyses below yield the same conclusions.

Investment efficiency is measured as follows. We run a regression of investment on Tobin's Q, which we refer to as “Q”, with an assortment of firm and country controls, and use the coefficient on Q as the proxy for the sensitivity of investment to Q. Following Baker et al. (2003), we use two measures of investment. Investment 1 equals capital expenditures plus 
research and development expenses $(\mathrm{R} \& \mathrm{D})$ as a share of total assets. Investment 2 equals capital expenditure plus R\&D plus all selling, general, and administrative (SG\&A) expenses as a share of total assets.

Appendix Table A.1 and Table 1 provide information on these firm-level variables. For example, EBIT to assets ranges from -0.53 to 0.49 with a standard deviation of 0.12 . The Net income to assets and Cash flow to assets exhibit similar diversity. Firm employment ranges from 0 to 13 , with a sample mean of 7 and a standard deviation of 1 . The reported values on Investment 1 and Investment 2 imply that there are firms making zero real investment in some years, while firms in the $75^{\text {th }}$ percentile of the investment distribution are investing equal to about ten percent of assets. Furthermore, as defined in Table A.1 and summarized in Table 1, we use data on several other firm characteristics, such as firm size, leverage, and Tobin's Q. To reduce the potential impact of outliers, we winsorize firm-level variables at $1 \%$ and $99 \%$ levels.

Figures 1 - 3 suggest that following systemic banking crises Proceeds of IPO/SEO, EBIT to assets, and the number of employees relative to firm assets fall less in countries with larger values of the Anti-self-dealing index. We provide simple graphs of firm equity financing, performance, and employment following a crisis while differentiating between high and low shareholder protection countries. For each firm, we compute the change in firm outcome variables from the average over the pre-crisis period (years $t-3$ through $t$ - 1 ) to the average during the crisis period (years $t$ to $t+3$ ), where $t$ in this case refers to the start-year of the banking crisis. Then, for firms in countries above (High) and below (Low) the median values of the Anti-selfdealing index, we compute the average value of these changes. Figure 1 shows that Proceeds of IPO/SEO drops on average by about $0.7 \%$ of assets during a crisis in Low Anti-self-dealing law countries and drops by $0.4 \%$ in High Anti-self-dealing law countries. Similarly, Figures 2 and 3 
indicate that firm profits and firm employment fall less in high shareholder protection countries than in other countries during a banking crisis.

\subsection{Industrial external finance dependence}

To evaluate the spare tire view, we examine whether the particular firms identified by the spare tire view as most likely to benefit from stronger shareholder protection actually do benefit more when a banking crisis hits. In particular, firms that depend heavily on raising money from banks and capital markets will benefit more from stronger shareholder protection laws when a banking crisis hits than firms that don't need any external financing in the first place, i.e., having a spare tire is most useful when the tires on a car are more easily punctured. To assess this view, we follow Rajan and Zingales (1998) and use data on U.S. companies to calculate the degree to which each industry depends on external finance.

Financial dependence equals the difference between capital expenditures and cash flow from operations divided by capital expenditures. The index is calculated at the three-digit U.S. SIC level. Rajan and Zingales (1998) and others use U.S. firms as a benchmark under the assumption that U.S. financial markets are comparatively developed, so that the U.S. Financial dependence measures proxy for the technological level of financial dependence, not the level shaped by frictions in financial markets. Thus, an extensive body of research (1) treats the Financial dependence indicator as reflecting the technology-determined demand for external finance in the United States and (2) assumes that this measure provides information on the technology-determined demand for external finance in other economies as well. Based on this literature, we assess the question: Are the attenuating effects of stronger shareholder protection laws on firm performance in response to a crisis greater for firms that depend heavily on external 
finance? Or, more formally, we assess the coefficient estimate on the triple interaction term of banking crises, the Anti-self-dealing index, and financial dependence by splitting the sample into High and Low Financial dependence industries and examining the Anti-self-dealing*Crisis terms in subsamples. To accommodate our relatively longer sample period, we modify the fixeddecade window in the original Rajan and Zingales (1998) and use instead a rolling ten-year window, [t-10, $t-1]$, where $t$ denotes the start-year of each crisis. For instance, we take the U.S. firms' data over 1997-2006 to calculate the Financial dependence index for industries in the United Kingdom, which had a banking crisis that started in 2007.

\subsection{Other country characteristics}

To help isolate the relationship between firm performance and the interaction between the existence of a systemic crises and stronger shareholder protection laws, we control for the potential effect of other national characteristics, Macro controls. We do this by including the interaction between the existence of systemic crises and the following national traits.

GDP per capita equals the natural logarithm of real gross domestic product (GDP) per person measured three years before the crisis. When interacted with the crisis dummy variable and included in the firm performance regressions, this term assesses whether firms perform better in response to a crisis in comparatively well-developed economies.

Stock market development equals the ratio of stock market capitalization to GDP measured three years before the crisis. When interacted with the crisis dummy variable and included in the firm performance regressions, this term assesses whether firms perform better in response to a crisis in economies with more highly developed stock markets. 
Private credit contraction equals the slowdown in credit growth, measured as the average annual growth rate in bank credit to private firms between $t-3$ and $t-1$, where $t$ is the start-year of the crisis, minus the minimum annual growth rate of credit during the period between $t$ and $t+3$. In this way, we control for the size of the crisis, not just the existence of a systemic crisis.

Financial institutions development equals credit by deposit money banks and other financial institutions as a share of GDP, measured at three years before the start of the crisis.

Legal protection and institutional quality. In robustness tests, we also control for a broader index of legal system effectiveness and institutional quality to determine whether shareholder protection laws in particular account for our findings, or whether broader institutions explain our findings. Specifically, the variable is constructed as the first principal component of eight institutional measures, namely Creditor rights index (Djankov et al., 2007), Protection of property rights (Fraser Institute), and six individual components of World Governance Index (i.e. rule of law, voice and accountability, political stability, government effectiveness, regulatory quality and control of corruption) constructed by Kaufmann et al. (2013).

We examine the interaction between shareholder protection laws and labor regulations in shaping firm employment during a banking crisis. To do so, we differentiate countries by those with above and below the median values of the Cost of firing workers index constructed by Botero et al. (2004). They quantify the cost to a firm of firing $20 \%$ of the workforce and it incorporates information on the notice period, severance pay, penalties, etc. In this way, we examine whether the relationship between firm employment and shareholder protection laws during a systemic banking crisis vary by the regulatory costs of firing workers. 


\subsection{Empirical methodology}

The baseline specification is as follows.

$$
\begin{gathered}
\text { Firm Outcome } e_{i, c, t}=\alpha_{0}+\alpha_{i}+\alpha_{t}+\boldsymbol{\beta} * \text { Anti_self_dealing }_{c} * \text { Crisis }_{c, t}+\theta * \text { Crisis }_{c, t}+ \\
\boldsymbol{\delta}^{\prime} \text { Macro_controls }_{c} * \text { Crisis }_{c, t}+\boldsymbol{\gamma}^{\prime} \text { Firm_controls }_{i, t-1}+\varepsilon_{i, c, t}
\end{gathered}
$$

where Firm Outcome Orc,t $_{\text {refers }}$ to equity financing, dividend payments, profitability, or employment by firm $i$, in country $c$, during year $t, \alpha_{0}$ and $\alpha_{i}$ are firm and year fixed effects respectively; and Anti_self_dealing ${ }_{c} * \operatorname{Crisis}_{c, t}$ is the interaction of the Anti-self-dealing index for country $c$ and the systemic crisis indicator, Crisis $_{c, t}$, which equals one for $t$ through $t+3$ and zero otherwise. Note that all time invariant country characteristics, including the independent term $A n t i \_s e l f \_d e a l i n g$, are subsumed in the firm fixed effects.

In the specification, Macro_controls $c_{c}$ denotes a set of country-level controls including GDP per capita, Financial institutions development, Stock market development, and Private credit contraction. Including the interaction between Crisis $_{c, t}$ and Macro_controls allows for firm outcomes following a crisis to vary by the level of economic development, the level of development of financial intermediaries, the degree of stock market development, and the size of the banking crisis. Including these controls also helps isolate the independent association between firm outcomes following a crisis and the strength of shareholder protection laws.

Finally, Firm_controls int-1 $_{\text {c }}$ includes time-varying firm characteristics (e.g., Firm size, Leverage, and Tobin's Q), and $\varepsilon_{i, c, t}$ denotes the error term. When the dependent variable is Firm employment, we split the sample between countries that have values above and below the median 
of the Cost of firing workers index. Throughout our analyses, we use ordinary least squares (OLS), with heteroskedasticity robust standard errors clustered at the country level to account for the potential correlations among firms within a country. The results hold when clustering at the country-year level or when using two-way clustering by country and year.

Before presenting the empirical results, it is worth noting that shareholder protection laws do not account for cross-country differences in the severity of banking crises, as measured by Private credit contraction. There might be concerns that shareholder protection laws influence the severity of banking crises, not the ability of firms to recover from crises. The evidence presented in Appendix Table A.3, however, suggests that there is not a statistically significant relation between Private credit contraction and Anti-self-dealing.

\section{Empirical Results: Equity Financing and Dividend Payout Policies}

\subsection{Equity financing}

We begin our investigation of the spare tire view by examining equity financing. In response to a systemic banking crisis, do firms in countries with stronger shareholder protection laws experience a smaller reduction in the amount of funds raised through equity issuances than those in countries with weaker shareholder protection laws? And, is the relationship between equity financing and shareholder protection laws following a crisis most pronounced for firms in industries that rely heavily on external finance?

Table 2 reports nine regressions assessing whether firms experience a smaller drop in funds raised through equity issuances following a banking crisis in countries with stronger Antiself-dealing laws. We employ the econometric design specified above in equation (1), where the dependent variable is Equity issuance in columns (1) - (3) and Proceeds of IPO/SEO in columns 
(4) - (9). Equity issuance infers equity issuances from a firm's balance sheet, and Proceeds of IPO/SEO is based on transactional-level data. The variable of interest is the interaction term, Anti-self-dealing*Crisis. Using Equity issuance as the dependent variable, column (1) provides results for the full sample of manufacturing firms, while columns (2) and (3) splits the sample between firms in industries with above the median values of Financial dependence and firms in industries with below the median values respectively. Columns (4) - (6) present corresponding results where Proceed of IPO/SEO is the dependent variable for the full sample of manufacturing firms. Columns (7) - (9) repeat these analyses when eliminating all IPOs from the Proceed of IPO/SEO analyses. This involves only a small reduction in the number of observations (1.3\%) because our sample only includes publicly listed companies. Only a few firms (15) issued IPOs during the period just before the crisis $[t-3, t-1]$. An additional six firms are classified by SDC as issuing IPOs after the onset of the crisis [t, $t+3]$, although they were publicly listed firms during this period. In columns (7) - (9), we eliminate the observations on these 21 firms.

The results from the Equity issuance analyses in columns (1) - (3) are consistent with the spare tire view. Consider the full sample estimates for the Equity issuance measure in column (1). Anti-self-dealing*Crisis enters positively and significantly. Economically, a one standard deviation increase in the Anti-self-dealing index enables a firm to issue additional equity equal to about $0.8 \%$ of its total assets $(=0.0357 * 0.214)$ during a systemic banking crisis. This is not small, as it is equivalent to $26 \%$ of the sample mean of equity issuances per year, and seven times larger than the sample median.

The results from the Proceeds of IPO/SEO analyses are also consistent with the spare tire view. As shown in columns (4) - (6), following the onset of a systemic banking crisis, Proceeds of IPO/SEO is larger in countries with stronger shareholder protection laws among firms in 
industries that are heavily dependent on external finance, but not for firms in Low Financial dependence industries. The estimates suggest that a one standard deviation increase in the Antiself-dealing index (0.214) is associated with a 0.4 percentage point increase in the Proceeds of IPO/SEO. This increase is equivalent to $16.4 \%$ of the sample mean (see Table 1 ). Consistent with the prediction of the spare tire view, the split sample analyses suggest that the positive impact of shareholder protection on equity financing is larger in industries that are more heavily dependent on external finance. Specifically, the estimated coefficients suggest that a one standard deviation increase in the Anti-self-dealing index is associated with a 1.1 percentage point increase in Proceeds of IPO/SEO. These results also hold for the sample of SEO firms only, which are reported in columns (7) - (9). For firms that were already public, proceeds from seasoned equity offerings are much larger in countries with stronger shareholder protections in industries with high Financial dependence, but not in industries with low Financial dependence.

As shown, these results hold when controlling for many other potential explanatory factors. In particular, we were concerned that Anti-self-dealing laws might be highly correlated with the overall economic development, the size of the banking system, the level of stock market development, or the size of the credit contraction during the crisis. Thus, we control for the interaction between banking crises and GDP per capita, Financial institutions development, Stock market development, and Private credit contraction across the Table 2 specifications. Thus, the findings suggest that the relationships between shareholder protection laws and corporations’ ability to raise alternative funds from the equity market do not simply reflect the level of stock market development before the crisis, the overall level of economic, bank, or stock market development, or the size of the banking crisis. Thus, the results do not indicate that countries 
with stronger Anti-self-dealing laws merely have smaller systemic banking crises. The Table 2 results are consistent with the spare tire hypothesis.

To further illustrate the economic sizes of the coefficients, we use the estimates reported in column (5) as an example. Consider a hypothetical "average" country with average values of the Anti-self-dealing index (0.437), and a hypothetical "strong” shareholder protection rights country with all of the same traits as the average country except that it has an Anti-self-dealing index that is one standard deviation (0.214) greater, so that the value for the strong country is 0.651. For these two hypothetical countries, hold all other country traits (including GDP per capita, Financial institutions development, Stock market development, and Private credit contraction) constant at the sample means. Using the coefficient estimates in column (5), we estimate that for industries that depend heavily on external finance, the country with strong Antiself-dealing will raise $82 \%$ more funding through equity financing than the average country during systemic banking crises. ${ }^{1}$

\subsection{Dividend payments}

Dividend payout policies are another mechanism through which shareholder protection laws could shape how firms respond to banking crises. Stronger shareholder protection laws could also allow firms to make larger cuts in dividend payouts during crises and thereby more effectively cushion the impact of the crisis on firm performance. More specifically, the "agency"

\footnotetext{
${ }^{1}$ Using the coefficient estimate in column (5) of Table 2 and recalling that Proceeds of IPO/SEO equals the amount of funds raised through equity issuances as a fraction of the firm's total assets, the coefficient estimates suggest that for high financial dependent industries in an 'average' country, firms raise equity equal to $1.3 \%$ of its total assets during a crisis (i.e., $0.01322=(0.0508 * 0.437)-0.0327+(0.0067 * 9.242)-(0.0269 * 0.801)+(0.0175 * 0.588)$ $(0.0898 * 0.3))$. In turn, in a country with stronger Anti-self-dealing index, those firms will raise $2.4 \%$ of total assets (i.e., $\quad 0.024095=(0.0508 * 0.651)-0.0327+(0.0067 * 9.242)-(0.0269 * 0.801)+(0.0175 * 0.588)-(0.0898 * 0.3))$. Thus, these estimates suggest that firms in the stronger Anti-self-dealing country will raise $82 \%$ more equity financing during a crisis than firms from an average country.
} 
view of payout policy (La Porta et al., 2000) stresses that when the legal system better protects minority shareholders and gives them confidence that they can force higher payouts in the future, these shareholders will be more willing to postpone receipt of their dividend payments during a crisis in expectation of the higher expected payouts afterwards. From this perspective firms operating in economies with stronger shareholder protections will reduce dividend payments more and retain a larger proportion of earnings for working capital or investments. We assess this potential channel through which shareholder protection laws can shape corporate responses to crises.

The results presented in Table 3 do not offer significant evidence supporting this dividend payout channel. We examine each of the four measures of dividend payment policies defined above. The coefficient estimate on Anti-self-dealing*Crisis is statistically insignificant across four different measures, namely Dividend yield, Dividend to cash flow, Dividend to assets, and Dividend to sales. Moreover, we find no significant impact of shareholder protection laws on dividend payments in either High or Low Financial dependence industries. The data do not provide compelling evidence for rejecting the null hypothesis that in response to a systemic banking crisis, corporate dividends do not fall more in countries with stronger Anti-self-dealing laws.

\subsection{Equity financing in the banking sector}

Equity markets could also provide "spare tire" financing to banks in a crisis. If the value of bank assets falls in a crisis, banks in countries with strong shareholder protection laws might face fewer barriers when raising equity to satisfy capital requirements. Similarly, if there is a flight to safety and bank deposits rise, then banks will need to raise equity to finance loans. Anti- 
self-dealing laws could therefore also influence how banks respond to a crisis: it might be easier for banks in countries with better legal protection of shareholders to raise equity during the crisis.

The results presented in Table 4 indicate that banks in economies with stronger Anti-selfdealing laws raise more money through equity issuances during banking crises than banks in economies with weaker shareholder protection laws. We use the same econometric specification as in the evaluation of manufacturing firms in Table 2. Columns (1) - (2) provide information on financial institutions, including commercial banks, savings banks, credit institutions, and bank holding companies as the banking sector. As reported in column (1), the interaction term, Antiself-dealing*Crisis, enters positively and significantly. Its coefficient is statistically significant at 1\%. The economic magnitude is nontrivial: a one standard deviation improvement in the Antiself-dealing index $(0.214)$ is estimated to raise the proceeds from new equity issuance over crises by 0.48 percentage points, which is $22.8 \%$ of the standard deviation of the Proceeds of IPO/SEO for the banking industry (see Table 1). Given that the sample mean of the Proceeds of IPO/SEO for the banking industry is $0.4 \%$, the effect is economically significant. As in Table 2, Table 4 column (2) limits the sample to banks that were already public before the onset of the crisis window, $t-3$, so that it only includes SEOs. For this subsample, the Anti-self-dealing*Crisis enters positively and significantly and the estimated effect remains almost unchanged. In columns (3) - (4), we repeat the analyses in columns (1) and (2) while restricting the sample to commercial banks. As shown, the results are virtually identical.

These findings suggest that easing the ability of banks to issue equity is an additional channel, beyond the direct issuance of equity by manufacturing firms discussed above, through which shareholder protection laws might affect economic recoveries from systemic banking crises. We now turn our focus from equity issuances to firm performance and employment. We 
focus on the direct link between shareholder protection laws and firm performance and employment by controlling for the change in bank credit to private firms during systemic crises.

\section{Empirical Results: Firm Performance, Employment, and Investment Efficiency}

\subsection{Firm performance and employment}

We now examine whether strong shareholder protection laws help reduce the adverse impact of the crisis on firm performance and employment. Table 5 shows that during a systemic banking crisis, firms in countries with strong shareholder protection laws perform better than those in countries with weaker shareholder protection laws. As reported in columns (1) - (3), during a crisis, EBIT to assets, Net income to assets, and Cash flow to assets are all significantly higher in countries with larger Anti-self-dealing values than they are in countries with weaker shareholder protection laws. The crisis dummy enters negatively and statistically significantly. Taken together, this suggests that banking crises are associated with a drop in firm performance, but this drop is less pronounced in countries with stronger Anti-self-dealing laws.

The economic sizes of the estimated coefficients are large. Consider the EBIT to assets regression. And again, consider a hypothetical average country with the average level of the Anti-self-dealing index (0.437), and a stronger shareholder protection country with a value of the index that is one standard deviation higher (0.651), holding all the other macro controls constant at their sample average. For the average country, the coefficient estimates in column (1) suggest that a systemic crisis reduces profits by about $3.35 \%$ of a firm's total assets. ${ }^{2}$ Given that the coefficient estimate on Anti-self-dealing*Crisis enters with a value of 0.0557 , we estimate that

\footnotetext{
${ }^{2}$ We obtain these estimates by plugging in the values with the corresponding coefficient estimates from column (1) of Table 5: a systemic banking crisis will reduce EBIT to assets in the average country by $3.35 \%(=(0.0557 * 0.437)-$ $0.107+(0.00684 * 9.242)-(0.00409 * 0.801)-(0.00604 * 0.588)-(0.0241 * 0.300))$.
} 
the drop in EBIT to assets for the strong shareholder protection country will only be $2.16 \%$ of total firms assets. ${ }^{3}$ Thus, compared to the average country, the strong shareholder rights country experiences a 36\% smaller drop in EBIT to assets ${ }^{4}$. To illustrate this difference using countries, the difference in the Anti-self-dealing indexes between Norway (0.42) and Hungary (0.18) is about one standard deviation. Thus, our estimates suggest that the better spare tire in Norway buffers the adverse impact of a systemic banking crisis on firm profits more effectively than in Hungary.

Table 5 also indicates that the drop in Firm employment during a banking crisis is smaller in countries with stronger shareholder protection laws when the regulatory-induced costs of firing workers is not too high. If labor regulations make it prohibitively expensive to fire workers, then an effective spare tire channel for raising external finance is likely to have a negligible effect on firm employment decisions during a crisis. We test this by splitting the sample between countries with above the median values of the Cost of firing workers index developed by Botero et al. (2004) and countries with below the median values. As listed in Appendix Table A2, there is considerable cross-country variation in the degree to which labor regulations increase the costs of firing workers. At one end of the spectrum, Indonesia, India, Kazakhstan, Korea, Netherlands, Portugal, Russia, and Thailand all have values of the Cost of firing workers index greater than 0.6, while Japan and Nigeria have values less than 0.1 .

As reported in columns (4) and (5) of Table 5, the interaction term, Anti-selfdealing*Crisis, enters positively and significantly in the sample of countries with below the

\footnotetext{
${ }^{3}$ Similarly, according to the corresponding coefficient estimates from column (1): EBIT to assets in stronger shareholder protection law country will fall by $2.16 \%(=(0.0557 * 0.651)-0.107+(0.00684 * 9.242)-(0.00409 * 0.801)$ $(0.00604 * 0.588)-(0.0241 * 0.300))$.

${ }^{4}$ Since the Macro interaction controls enter insignificantly, we redid the analyses omitting these controls and obtain coefficient estimates on Anti-self-dealing*Crisis that are larger and statistically significant.
} 
median values of the Cost of firing workers index, while it enters insignificantly in the sample of countries with above the median values of the index. This result suggests that when regulations do not create prohibitively high costs to firms of adjusting their labor forces, then having an alternative external financing source during a crisis is associated with a smaller reduction in firm employment. However, when the regulatory-induced costs of firing workers dominate firm employment decisions, then the spare tire mechanism plays no role. More formally, the estimated coefficient on Anti-self-dealing*Crisis among countries with below median firing costs is 0.122 , which is statistically significant at the one percent level, but the estimated coefficient among countries with high firing cost is statistically insignificant.

The point estimates suggest that the relationship is economically meaningful. Again, consider an "average” country — a country with average Anti-self-dealing laws, GDP per capita, Financial institutions development, Stock market development, and Private credit contraction, and compare it to a country with "strong” shareholder protection laws-a country with a one standard deviation above the mean value of the Anti-self-dealing index (0.651), holding all the other characteristics constant at their average levels. The estimated coefficients in column (4) suggest that a systemic banking crisis will reduce firm-level workforce in the average country by $17.4 \%$, but workforce in the strong shareholder protection law country will fall by $14.8 \%{ }^{5}$ Thus, the estimated drop in firm employment is almost $15 \%$ less in the country with strong shareholder protection laws.

\footnotetext{
${ }^{5}$ We obtain these estimates by plugging in the values with the corresponding coefficient estimates from column (4) of Table 5: a systemic banking crisis will reduce firm employment in the average country by $17.4 \%(=0.122 * 0.437-$ $0.333+0.0219 * 9.242-0.00121 * 0.801+0.00935 * 0.588-0.339 * 0.300$ ), but firm employment in the strong shareholder protection law country will fall by $14.8 \%(=0.122 * 0.651-0.333+0.0219 * 9.242-0.00121 * 0.801+0.00935 * 0.588-$ $0.339 * 0.300)$. We can interpret the impact on firm employment as percentage change because it is defined as the natural logarithm of total number of workers in a firm.
} 
Consistent with previous analyses, we control for the interactions of banking crises and GDP per capita, Financial institutions development, Stock market development, and Private credit contraction throughout all the columns in Table 5. Furthermore, we also control for firm and year fixed effects, and time-varying firm traits (Firm size, Leverage, and Tobin’s Q).

In Table 6, we extend these analyses and also control for the interaction between the systemic crisis dummy and (a) an index of the Rule of law that measures the degree to which the law, rather than more arbitrary and potentially corrupt factors, influence private and official contracts and (b) an overall index of the Legal protection and institutional quality provided to private agents, which incorporates information on the legal rights of debt holders, the protection of private property, the accountability of political officials, political stability, government effectiveness, regulatory quality, the Rule of law, and control on official corruption. The effects of the Anti-self-dealing index on firm performance and employment remain statistically significant and economically meaningful after taking into account these additional factors. Furthermore, when we include these additional interactions terms into the equity financing analyses presented in Table 2, the results hold.

\subsection{Firm performance and employment: Differentiating by Financial dependence}

An additional implication of the spare tire view is that during a crisis, the positive relationships between firm outcomes and the Anti-self-dealing index should be larger among firms that rely heavily on external finance. To test this prediction, we again split firms into those that depend heavily on external finance, High Financial dependence, and those firms in industries with below the median level external financial dependence, Low Financial dependence. 
Table 7 provides these subsample analyses for firm performance and employment. Panel A provides the results on EBIT to assets, Net income to assets, and Cash flow to assets, while Panel B provides the findings on Firm employment, while further splitting the sample by countries with below and above the median values of the Cost of firing workers index. The regressors are the same as those in Table 5.

The results reported in Table 7 are consistent with the spare tire prediction. The estimated coefficient on the Anti-self-dealing*Crisis interaction term is larger for firms in industries with High Financial dependence than for firms in Low Financial dependence industries. That is, during a banking crisis, shareholder protection laws are more important for firms that rely more heavily on external finance. For instance, consider the EBIT to assets analyses as reported in columns (1) and (2). The estimated coefficient on the Anti-self-dealing*Crisis interaction term is 0.0911 among firms in High Financial dependence industries, but only 0.0327 among firms in Low Financial dependence industries. Although both estimates are significantly different from zero, the two coefficient estimates are significantly different from each other at the $1 \%$ significant level, as reported in the table. In a systemic crisis, the beneficial effects of shareholder protection laws on firm performance and firm employment are greater among firms that depend heavily on external financing for their success. According to Panel B, during systemic crises, the dampening effect of stronger shareholder protection laws on firm employment, especially among firms in High Financial dependence industries, only exists in the sample of countries in which the Cost of firing workers is smaller than the median. 


\subsection{Investment efficiency}

The spare tire view also yields predictions about the impact of systemic banking crises on real investment efficiency. When banking crises reduce the flow of credit to firms that rely on external financing to fund their investments, this impedes the ability of those firms to exploit value-enhancing projects, with adverse repercussions on investment efficiency. If, however, stronger Anti-self-dealing laws ease corporate financial constraints during banking crisis, then such laws will dampen the adverse effects of the crisis on investment efficiency for firms that rely on external funding to make those investments.

To evaluate whether investment efficiency falls less in response to a banking crisis in economies with stronger Anti-self-dealing laws, we employ a commonly used measure of investment efficiency: the sensitivity of real investment to Tobin's $Q$. A key assumption underlying this proxy is that the common empirical measures of Tobin's $Q$, the market value of corporate liabilities relative to the book value of those liabilities, provide a sound estimate of the market value of installed capital relative to its replacement value. If this holds, then high Tobin's $Q$ values (conditional on Tobin's $Q>1$ ) signal that the market's expected increase in firm value from the firm investing more capital is greater than the cost of that capital. This would tend to encourage firm investment. Therefore, if real investment is insensitive to Tobin's Q, this suggests, albeit imperfectly, that something is impeding the efficiency of firm investment. As defined above, we use two measures of real investment to gauge the sensitivity of investment to $Q$ : Investment 1 only includes capital and R\&D expenditures, while Investment 2 also includes other investment expenditures on selling and general and administrative investments.

Methodologically, we employ a standard real investment model, where the dependent variable is one of our measures of investment. Besides including the lagged value of Tobin's $Q$ 
and the contemporary measure of cash flow, the real investment model includes the interaction terms, Tobin's $Q^{*}$ Crisis and Anti-self-dealing*Crisis, and the triple interaction term, Anti-selfdealing*Tobin's $Q *$ Crisis. The coefficient estimate on the triple interaction term captures the extent to which shareholder protection laws mitigate the adverse effects of a systemic banking crisis on investment efficiency, while the coefficient estimate on the Tobin's $Q^{*}$ crisis interaction term captures the impact of a systemic crisis on investment efficiency in a country with an Antiself-dealing index of zero. Since the link between systemic banking crisis and firm investment efficiency might be particularly pronounced for firms that depend on external finance to make investments, we also conduct the analyses when splitting the sample between firms in industries with High or Low Financial dependence. These regressions also control for firm and year fixed effects, as well as the full array of Macro interaction controls used in earlier tables.

The Table 8 results suggest that stronger shareholder protection laws mitigate the adverse effects of systemic crises on investment efficiency. The interaction term, Tobin's $Q^{*}$ Crisis enters negatively and significantly in the full sample regressions and in the sample limited to firms in High Financial dependence industries. This indicates that systemic crises exert a direct, negative effect on investment efficiency. The estimated coefficient on the triple interaction term, Anti-selfdealing*Tobin's $Q^{*}$ Crisis, in the full sample and High Financial dependence firms indicates that during banking crises, stronger shareholder protection laws boost investment efficiency. We are not the first to find that the law shapes investment efficiency. For instance, Mclean et al. (2012) find that stronger investor protection laws boost the efficiency of corporate investment. We are, however, the first to show that when economies experience systemic banking crises, stronger shareholder protections facilitate equity issuances and dampen the adverse effects of banking crises on investment efficiency. 
To assess the economic size of the effect, we consider the full sample results using Investment 1 in column (1). We again compare a country with an average value of the Anti-selfdealing index (0.437) and a country with a high Anti-self-dealing index of one standard deviation greater than average (0.651), holding the other macro controls at their average levels. Furthermore, for simplicity, we consider firms with Tobin’s Q equal to one. Thus, the estimated coefficients indicate that investment efficiency drops by $0.005(=-0.019+0.031 * 0.437)$ for this representative firm in the "average” firm country, but would essentially remain unchanged 0.001 $(=-0.019+0.031 * 0.651)$ in the same representative firm in the high Anti-self-dealing country.

Columns (2) and (3) for Investment 1 and columns (5) and (6) for Investment 2 provide the same analyses on subsamples of firms with High and Low Financial dependence respectively. The coefficient of interest is statistically significant at the one percent level in the sample of firms in high financial dependent industries, but not for firms in the sample of low financial dependent industries. For the Investment 2 analyses, we also discover that the coefficient estimates on the triple interaction term in the High and Low Financial dependence regressions are significantly different from each other, though this does not hold for the Investment 1 results. The Table 8 findings are consistent with the view that stronger shareholder protections dampen the negative impact of banking crises on investment efficiency, and there is some evidence that these effects are particularly large for firms that depend on external financing to undertake capital investments. 


\section{Conclusion}

Do shareholder protection laws influence how firms respond to systemic banking crises? While considerable research examines the impact of shareholder protection laws on the operation of stock markets, corporate financial decisions, and the efficiency of corporate investment, we provide the first assessment of the role of shareholder protection laws in shaping the response of firms to banking crises. In particular, we provide empirical evidence on the following questions: When economies experience a systemic banking crisis, do pre-crisis shareholder protection laws shape how firms respond to the crisis in terms of equity financing, profitability, employment, and investment efficiency? Do stronger shareholder protection laws dampen the adverse impact of banking crises on firms and workers?

We find that in response to systemic banking crises, firms in countries with stronger shareholder protection laws tend to experience a smaller drop in equity issuances, profits, employment, and investment efficiency. These results hold particularly strongly for firms that depend heavily on external finance, further suggesting that shareholder protections ameliorate the adverse effects of banking crises by providing an alternative financing mechanism. Moreover, the findings do not reflect (a) the level of stock market development prior to the crisis, (b) the overall level of economic development, (c) the severity of the credit contraction from the crisis, (d) the size of the banking sector, (e) the overall level of legal and institutional development. Taken together, the findings are consistent with the spare tire view: when banking crises hit, stronger shareholder protection laws contribute to a legal infrastructure that allows stock markets to act as an alternative source of external financing, easing the ramifications of banking crises on the economy. 


\section{References}

Atanassov, J., Kim, E.H., 2009. Labor and Corporate Governance: International Evidence from Restructuring Decisions. Journal of Finance 64, 341-374.

Baker, M., Stein, J.C., Wurgler, J., 2003. When Does the Market Matter? Stock Prices and the Investment of Equity-Dependent Firms. The Quarterly Journal of Economics 118, 969-1005.

Beck, T., Demirgüç-Kunt, A., Levine, R., 2003. Law, Endowments, and Finance. Journal of Financial Economics 70, 137-181.

Beck, T., Levine, R., Levkov, A., 2010. Big Bad Banks? The Winners and Losers from Bank Deregulation in the United States. Journal of Finance 65, 1637-1667.

Becker, B., Ivkovic, Z., Weisbenner, S., 2011. Local Dividend Clienteles, Journal of Finance 66, 655-683.Botero, J.C., Djankov, S., La Porta, R., Lopez-de-Silanes, F., Shleifer, A., 2004. The Regulation of Labor. The Quarterly Journal of Economics 119, 1339-1382.

Brockman, P., Chung, D.Y., 2003. Investor Protection and Firm Liquidity. The Journal of Finance 58, 921-937.

Chodorow-Reich, G., 2014. The Employment Effects of Credit Market Disruptions: Firm-level Evidence from the 2008-9 Financial Crisis. The Quarterly Journal of Economics 129, 1-59.

Čihák, M., Demirgüç-Kunt, A., Feyen, E., Levine, R., 2013. Financial Development in 205 Countries, 1960 to 2010. Journal of Financial Perspectives 12, 1-19.

Demirguc-Kunt, A., Maksimovic, V., 1998. Law, Finance, and Firm Growth. Journal of Finance 53, 2107-2137.

Djankov, S., La Porta, R., Lopez-de-Silanes, F., Shleifer, A., 2008. The Law and Economics of Self-dealing. Journal of Financial Economics 88, 430-465.

Djankov, S., McLiesh, C., Shleifer, A., 2007. Private Credit in 129 Countries. Journal of Financial Economics 84, 299-329.

Greenspan, A., 1999. Do Efficient Financial Markets Mitigate Financial Crises? Before the Financial Markets Conference of the Federal Reserve Bank of Atlanta, Sea Island, Georgia.

Greenspan, A., 1999. Lessons From the Global Crises. Before the World Bank Group and the International Monetary Fund, Program of Seminars, Washington, D.C.

Kaufmann, D., Kraay, A., Mastruzzi, M., 2011. The Worldwide Governance Indicators: Methodology and Analytical Issues. Hague Journal on the Rule of Law 3, 220-246.

Kroszner, R.S., Laeven, L., Klingebiel, D., 2007. Banking Crises, Financial Dependence, and Growth. Journal of Financial Economics 84, 187-228. 
La Porta, R., Lopez-de-Silanes, F., Shleifer, A., 1999. Corporate Ownership around the World. The Journal of Finance 54, 471-517.

La Porta, R., Lopez-De-Silanes, F., Shleifer, A., Vishny, R.W., 1997. Legal Determinants of External Finance. The Journal of Finance 52, 1131-1150.

La Porta, R., Lopez-de-Silanes, F., Shleifer, A., Vishny, R.W., 1998. Law and Finance. Journal of Political Economy 106, 1113-1155.

La Porta, R., Lopez-de-Silanes, F., Shleifer, A., Vishny, R.W., 2000. Agency Problems and Dividend Policies around the World. The Journal of Finance 55, 1-33.

La Porta, R., Lopez-de-Silanes, F., Shleifer, A., Vishny, R.W., 2002. Investor Protection and Corporate Valuation. The Journal of Finance 57, 1147-1170.

Laeven, L., Valencia, F., 2012. Systemic Banking Crises Database. IMF Economic Review 61(2) 225-270.

Levine, R., Zervos, S., 1998. Stock Markets, Banks, and Economic Growth. American Economic Review, 537-558.

McLean, R.D., Zhang, T., Zhao, M., 2012. Why Does the Law Matter? Investor Protection and Its Effects on Investment, Finance, and Growth. The Journal of Finance 67, 313-350.

Morck, R., Yeung, B., Yu, W., 2000. The Information Content of Stock Markets: Why Do Emerging Markets Have Synchronous Stock Price Movements? Journal of Financial Economics 58, 215-260.

National Commission on the Causes and Consequences of the Financial and Economic Crisis in the United States, 2011. The Financial Crisis Inquiry Report. New York, NY: Public Affairs.

Pagano, M., Volpin, P., 2008. Labor and Finance. London Business School.

Pinkowitz, L., Stulz, R., Williamson, R., 2006. Does the Contribution of Corporate Cash Holdings and Dividends to Firm Value Depend on Governance? A Cross-Country Analysis. The Journal of Finance 61, 2725-2751.

Rajan, R.G., Zingales, L., 1998. Financial Dependence and Growth. The American Economic Review 88, 559-586.

Reinhart, C. M., Rogoff, K. S., 2009. This Time is Different: Eight Centuries of Financial Folly. Princeton University Press.

Wessel, D., 2009. In Fed We Trust. New York, NY: Crown Publishing Group. 


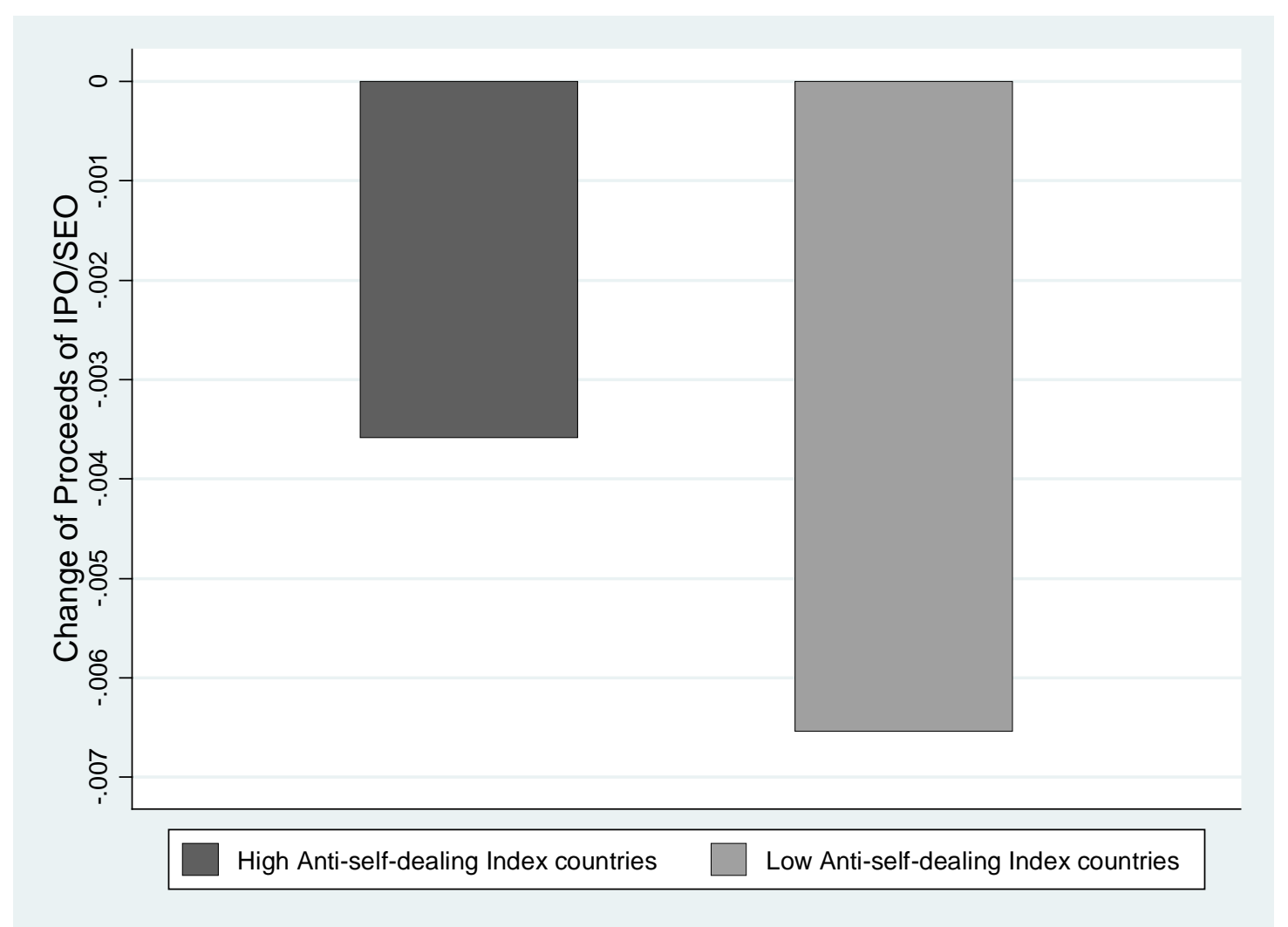

Figure 1. Firm equity issuances during a banking crisis, differentiating between countries with high and low Anti-self-dealing index values

Each bar in the figure represents the average change in the ratio of the total amount of funds raised through IPOs and SEOs to total assets (Proceeds of IPO/SEO) for firms in countries with above (High) and below (Low) the median value of the Anti-self-dealing index respectively. Specifically, we first calculate for each firm the difference between Proceeds of IPO/SEO during a crisis, $[t, t+3]$ and before the crisis, $[t-3, t-1]$. We then average this difference across all of the firms in High and Low Anti-self-dealing countries respectively. 


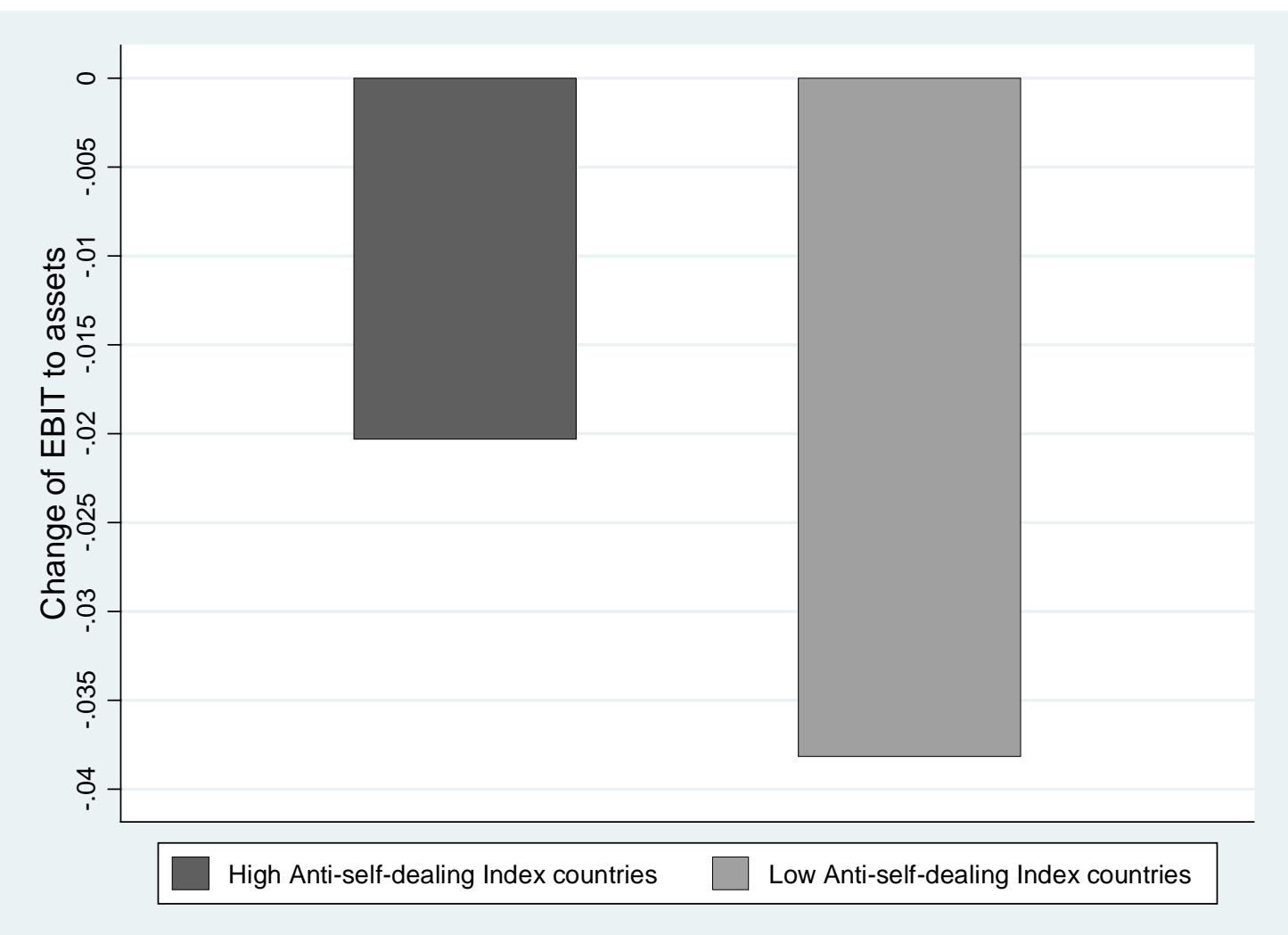

Figure 2. Firm profits during a banking crisis, differentiating between countries with high and low Anti-self-dealing index values

Each bar in the figure represents the average change of the ratio of earnings before income and taxes (EBIT) to total assets for firms in countries with above (High) and below (Low) the median value of the Anti-self-dealing index respectively. Specifically, we first calculate for each firm the difference between the ratio of EBIT to total assets during a crisis, $[t, t+3]$ and before the crisis, $[t-3, t-1]$. We then average this difference across all of the firms in High and Low Anti-selfdealing countries respectively. 


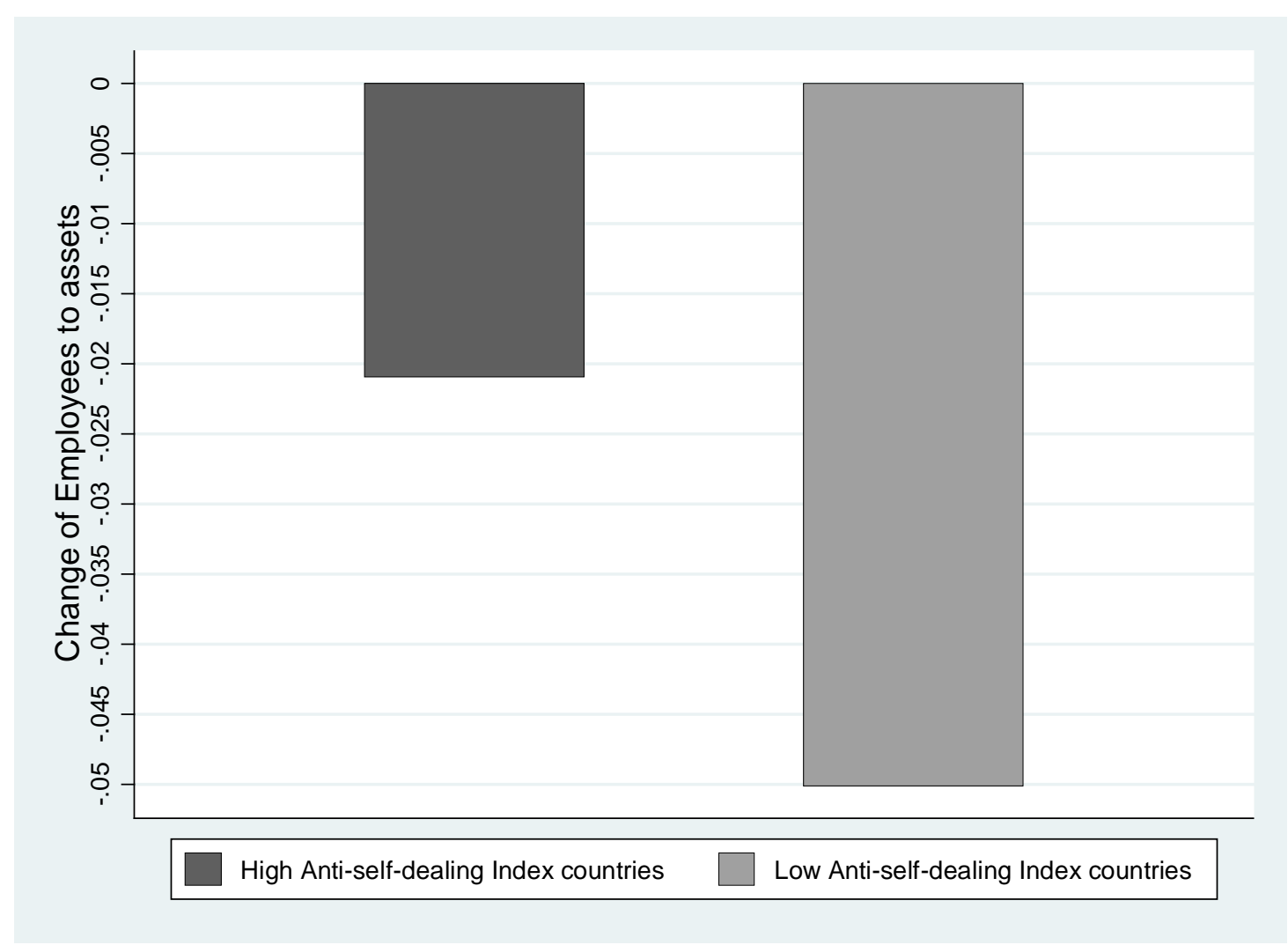

Figure 3. Firm employment during a banking crisis, differentiating between countries with high and low Anti-self-dealing index values

Each bar in the figure represents the average change in the ratio of the number of employees to total assets for firms in countries with above (High) and below (Low) the median value of the Anti-self-dealing index respectively. We multiply the ratio by 100 for expositional purposes. Specifically, we first calculate for each firm the difference between the natural logarithm of the ratio of the number of employees to total assets during a crisis, $[t, t+3]$ and before the crisis, [t-3, $\mathrm{t}-1]$. We then average this difference across all of the firms in High and Low Anti-self-dealing countries respectively. 


\section{Table 1 Summary statistics}

For the variables listed in the first column, this table provides the number of observations (N), the average value (Mean), the standard deviation (Sd), the minimum value (Min), the Maximum value (Max), and the values at the $25^{\text {th }}, 50^{\text {th }}$, and $75^{\text {th }}$ percentiles respectively. Each of the variables is defined in Appendix Table A.1.

\begin{tabular}{|c|c|c|c|c|c|c|c|c|}
\hline Variables & $\mathbf{N}$ & Mean & Sd & Min & 25th & 50th & 75th & Max \\
\hline & \multicolumn{8}{|c|}{ Country-level Measures } \\
\hline Anti-self-dealing index & 36 & 0.437 & 0.214 & 0.081 & 0.283 & 0.425 & 0.522 & 0.950 \\
\hline GDP per capita & 36 & 9.242 & 1.466 & 5.999 & 8.265 & 9.570 & 10.506 & 11.301 \\
\hline Financial institutions development & 36 & 0.801 & 0.508 & 0.121 & 0.314 & 0.737 & 1.130 & 1.997 \\
\hline Stock market development & 36 & 0.588 & 0.594 & 0.049 & 0.189 & 0.416 & 0.776 & 2.792 \\
\hline Private credit contraction & 36 & 0.300 & 0.230 & 0.018 & 0.105 & 0.241 & 0.471 & 0.780 \\
\hline Rule of law & 36 & 0.687 & 0.992 & -1.081 & -0.088 & 0.764 & 1.640 & 1.945 \\
\hline Legal protection and institutional quality & 35 & 0.095 & 2.484 & -4.434 & -2.343 & 0.252 & 2.727 & 3.479 \\
\hline \multirow[t]{2}{*}{ Cost of firing workers } & 35 & 0.465 & 0.177 & 0.036 & 0.358 & 0.527 & 0.605 & 0.688 \\
\hline & \multicolumn{8}{|c|}{ Firm-level Variables(Manufacturing industry) } \\
\hline Equity Issuance & 18494 & 0.029 & 0.149 & -0.275 & -0.007 & 0.001 & 0.018 & 1.195 \\
\hline Proceeds of IPO/SEO & 9393 & 0.024 & 0.126 & 0 & 0 & 0 & 0 & 1.277 \\
\hline Dividend yield & 21467 & 0.017 & 0.023 & 0.000 & 0.000 & 0.011 & 0.024 & 0.130 \\
\hline Dividend to cash flow & 20587 & 0.178 & 0.248 & 0.000 & 0.000 & 0.112 & 0.236 & 1.509 \\
\hline Dividend to assets & 21467 & 0.014 & 0.025 & 0.000 & 0.000 & 0.006 & 0.016 & 0.157 \\
\hline Dividend to sales & 21356 & 0.015 & 0.025 & 0.000 & 0.000 & 0.007 & 0.017 & 0.155 \\
\hline EBIT to assets & 23095 & 0.057 & 0.121 & -0.527 & 0.018 & 0.051 & 0.103 & 0.494 \\
\hline Net income to assets & 23415 & 0.021 & 0.103 & -0.540 & 0.001 & 0.021 & 0.060 & 0.352 \\
\hline Cash flow to assets & 22064 & 0.063 & 0.109 & -0.486 & 0.025 & 0.061 & 0.109 & 0.429 \\
\hline Employment & 20891 & 7.081 & 1.842 & 0 & 5.971 & 6.959 & 8.171 & 13.126 \\
\hline Investment 1 & 18318 & 0.076 & 0.079 & 0 & 0.028 & 0.055 & 0.097 & 0.541 \\
\hline Investment2 & 14352 & 0.297 & 0.207 & 0.018 & 0.162 & 0.245 & 0.370 & 1.318 \\
\hline Firm size & 23426 & 12.739 & 1.930 & 7.773 & 11.478 & 12.646 & 13.903 & 17.929 \\
\hline Leverage & 23426 & 0.250 & 0.175 & 0 & 0.105 & 0.238 & 0.373 & 0.700 \\
\hline Tobin's Q & 23426 & 0.255 & 0.443 & -0.665 & -0.016 & 0.185 & 0.442 & 1.893 \\
\hline
\end{tabular}

Firm-level Variables(Banking industry) 
Proceeds of IPO/SEO

Firm size

Leverage

Tobin's Q

Cash flow to assets

\begin{tabular}{cccccccc}
1763 & 0.004 & 0.021 & 0 & 0 & 0 & 0 & 0.415 \\
1763 & 16.627 & 1.998 & 9.227 & 15.401 & 16.605 & 17.860 & 20.530 \\
1763 & 0.241 & 0.217 & 0 & 0.042 & 0.195 & 0.380 & 0.862 \\
1763 & 0.047 & 0.114 & -0.398 & -0.001 & 0.020 & 0.058 & 1.570 \\
1763 & 0.007 & 0.034 & -0.419 & 0.001 & 0.003 & 0.011 & 0.628 \\
\hline
\end{tabular}




\section{Table 2 Anti-self-dealing and equity finance over crises, $[t-3, t+3]$}

This table reports regression results of the relation between the Anti-self-dealing index and firms' equity issuances during banking crisis episodes [t-3, $\mathrm{t}+3]$, where $t$ is the start year of a systemic banking crisis defined in Laeven and Valencia (2012). The dependent variables are Equity issuance in columns (1) - (3) and Proceeds of IPO/SEO in columns (4) - (9). Equity issuance equals the change in the book value of common equity plus the change in deferred taxes minus the change in retained earnings during a specific year $t$, all scaled by total assets at the close of year t-1. Proceeds of IPO/SEO equals the proceeds from public equity offerings during year $t$ as a share of total assets at the close of year $t-1$. Anti-self-dealing is an index of the degree to which the law protects minority shareholders from being expropriated by managers or controlling shareholders using self-dealing transactions. Crisis equals one in the start year of a crisis and for the three years afterwards, [t, $\mathrm{t}+3]$, and zero otherwise, [t-3, $\mathrm{t}-1]$. GDP per capita equals the natural logarithm of real GDP per capita, measured three years before the start year of the banking crisis. Financial institutions development equals the ratio of private credit by deposit money banks and other financial institutions to GDP, measured three years before the start year of the banking crisis. Stock market capitalization equals the ratio of stock market capitalization to GDP, measured three years before the start year of the banking crisis. Private credit contraction equals the average annual growth rate in bank credit to private firms between $t-3$ and $t-1$, where $t$ is the start-year of the crisis, minus the minimum annual growth rate of bank credit to private firms during the period between $t$ and $t+3$. Firm size (lag) equals the logarithm of total assets lagged one year. Leverage (lag) equals total debt divided by total assets lagged one year. Tobin's $Q$ (lag) equals Ln [(Market value of equity + book value of assets - book value of equity) / Book value of assets] lagged one year. Cash flow to assets equals (Net Income after dividends + Depreciations \& Amortizations) / Total assets lagged one year. In the column headings, "All” represents the full sample of firms and countries, while "High (Low) Financial dependence" represents the subsample of firms with Financial dependence above (below) the median value. Financial dependence measures the extent to which firms depend on external finance and is calculated at U.S. SIC 3-digit level following the method in Rajan and Zingales (1998). In columns (4) - (6), the dependent variable includes all IPO and SEO issuances. In columns (7) - (9), the dependent variable only includes firms that were already public three years before the crisis, i.e., SEO transactions only. P-values are reported in parenthesis and calculated using heteroskedasticity robust standard errors clustered at the country level. *, ${ }^{* *}$, and ${ }^{* * *}$ represent significant level at $10 \%, 5 \%$, and $1 \%$, respectively.

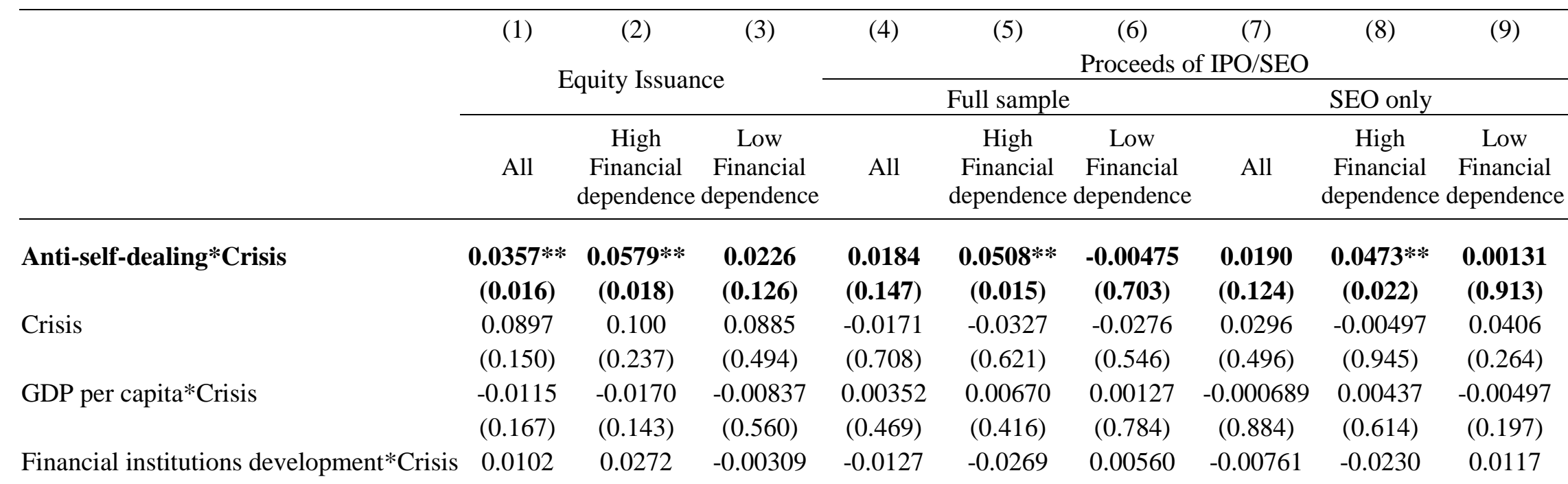




\begin{tabular}{|c|c|c|c|c|c|c|c|c|c|}
\hline & $(0.625)$ & $(0.448)$ & $(0.877)$ & $(0.223)$ & $(0.115)$ & $(0.553)$ & $(0.435)$ & $(0.169)$ & $(0.191)$ \\
\hline \multirow[t]{2}{*}{ Stock market capitalization*Crisis } & 0.00141 & 0.00776 & -0.00146 & $0.0114 *$ & $0.0175^{* *}$ & 0.00508 & $0.0105^{*}$ & $0.0164^{* *}$ & 0.00428 \\
\hline & $(0.830)$ & $(0.330)$ & $(0.847)$ & $(0.054)$ & $(0.036)$ & $(0.386)$ & $(0.072)$ & $(0.049)$ & $(0.427)$ \\
\hline \multirow[t]{2}{*}{ Private credit contraction*Crisis } & -0.0565 & -0.0698 & -0.0586 & -0.0414 & $-0.0898 *$ & 0.0141 & -0.0566 & $-0.0974 *$ & -0.00810 \\
\hline & $(0.168)$ & $(0.105)$ & $(0.346)$ & $(0.331)$ & $(0.077)$ & $(0.648)$ & $(0.167)$ & $(0.052)$ & $(0.784)$ \\
\hline \multirow[t]{2}{*}{ Firm size (lag) } & $-0.136 * * *$ & $-0.154 * * *$ & $-0.116 * * *$ & $-0.0642 * * *$ & $-0.0737 * * *$ & $-0.0504 * * *$ & $-0.0604 * * *$ & $-0.0684 * * *$ & $-0.0480 * * *$ \\
\hline & $(0.000)$ & $(0.000)$ & $(0.000)$ & $(0.000)$ & $(0.000)$ & $(0.000)$ & $(0.000)$ & $(0.000)$ & $(0.000)$ \\
\hline \multirow[t]{2}{*}{ Leverage (lag) } & $0.128^{* * *}$ & $0.195^{* * *}$ & 0.0630 & $0.0569 *$ & 0.0587 & $0.0579 *$ & $0.0565^{*}$ & 0.0574 & $0.0592 * *$ \\
\hline & $(0.000)$ & $(0.000)$ & $(0.123)$ & $(0.085)$ & $(0.202)$ & $(0.052)$ & $(0.077)$ & $(0.200)$ & $(0.042)$ \\
\hline \multirow[t]{2}{*}{ Tobin's Q (lag) } & $0.0933 * * *$ & $0.0997 * * *$ & $0.0837 * *$ & $0.0460 * * *$ & $0.0528 * * *$ & 0.0340 & $0.0458^{* * *}$ & $0.0520 * * *$ & 0.0349 \\
\hline & $(0.001)$ & $(0.000)$ & $(0.010)$ & $(0.000)$ & $(0.000)$ & $(0.111)$ & $(0.000)$ & $(0.000)$ & $(0.113)$ \\
\hline \multirow[t]{2}{*}{ Cash flow to assets } & $-0.163 *$ & -0.153 & $-0.179 *$ & -0.0636 & $-0.147 * *$ & 0.0467 & -0.0641 & $-0.153 * *$ & 0.0527 \\
\hline & $(0.081)$ & $(0.109)$ & $(0.076)$ & $(0.282)$ & $(0.020)$ & $(0.583)$ & $(0.277)$ & $(0.014)$ & $(0.533)$ \\
\hline \multirow[t]{2}{*}{ Constant } & $1.603 * * *$ & $2.022 * * *$ & $1.425 * * *$ & $0.810 * * *$ & $0.926 * * *$ & $0.629 * * *$ & $0.771^{* * *}$ & $0.857 * * *$ & $0.618 * * *$ \\
\hline & $(0.000)$ & $(0.000)$ & $(0.000)$ & $(0.000)$ & $(0.000)$ & $(0.000)$ & $(0.000)$ & $(0.000)$ & $(0.000)$ \\
\hline Firm FE & Yes & Yes & Yes & Yes & Yes & Yes & Yes & Yes & Yes \\
\hline Year FE & Yes & Yes & Yes & Yes & Yes & Yes & Yes & Yes & Yes \\
\hline Country cluster & 34 & 33 & 33 & 34 & 31 & 33 & 34 & 30 & 33 \\
\hline Observations & 18,494 & 9,136 & 9,358 & 9,393 & 4,676 & 4,717 & 9,272 & 4,613 & 4,659 \\
\hline Adjusted R2 & 0.306 & 0.327 & 0.280 & 0.184 & 0.211 & 0.148 & 0.178 & 0.207 & 0.140 \\
\hline \multirow{2}{*}{\multicolumn{2}{|c|}{$\begin{array}{l}\text { F statistic } \\
\left(\beta \_ \text {High- } \beta \_ \text {Low }=0\right)\end{array}$}} & \multirow{2}{*}{\multicolumn{2}{|c|}{$\begin{array}{c}3.46^{*} \\
(0.0627) \\
\end{array}$}} & & \multirow{2}{*}{\multicolumn{2}{|c|}{$\begin{array}{l}8.62 * * * \\
(0.0033) \\
\end{array}$}} & & \multirow{2}{*}{\multicolumn{2}{|c|}{$\begin{array}{c}6.06^{* *} \\
(0.0138) \\
\end{array}$}} \\
\hline & & & & & & & & & \\
\hline
\end{tabular}




\section{Table 3 Anti-self-dealing and dividend payments over crises}

This table reports regression results of the relation between corporate dividends and the Anti-self-dealing index during banking crisis episodes [t-3, $t+3$ ], where $t$ is the start year of a systemic banking crisis defined in Laeven and Valencia (2012). The dependent variables are Dividend yield, Dividend to cash flow, Dividend to assets, and Dividend to sales, which are cash dividends divided by market capitalization lagged one year, cash flow, total assets lagged one year, and sales in columns (1) - (3), (4) - (6), (7) - (9), and (10) - (12) respectively. Anti-self-dealing is an index of the degree to which the law protects minority shareholders from being expropriated by managers or controlling shareholders using self-dealing transactions. Crisis equals one in the start year of a crisis and for the three years afterwards, [t, $t+3]$, and zero otherwise, [t-3, t-1]. For the column headings, "All” represents the full sample of firms and countries, while "High (Low) Financial dependence" represents the subsample of firms with Financial dependence above (below) the median value. The Financial dependence measures the extent to which firms depend on external finance and is calculated at U.S. SIC 3-digit level following the method in Rajan and Zingales (1998). Firm-level controls include: the natural logarithm of total assets, the ratio of debt to assets, and Tobin's Q, which are all lagged one year relative to the dividend payout measures, and the ratio of firm's cash flow to its assets. Macro interaction controls include interactions between Crisis and (1) GDP per capita, (2) Financial institutions development, (3) Stock market development, and (4) Private credit contraction. GDP per capita equals the natural logarithm of real GDP per capita, measured three years before the start year of the banking crisis. Financial institutions development equals the ratio of private credit by deposit money banks and other financial institutions to GDP, measured three years before the start year of the banking crisis. Stock market capitalization equals the ratio of stock market capitalization to GDP, measured three years before the start year of the banking crisis. Private credit contraction equals the average annual growth rate in bank credit to private firms between $t-3$ and $t-1$, where $t$ is the start-year of the crisis, minus the minimum annual growth rate of bank credit to private firms during the period between $t$ and $t+3$. P-values are reported in parenthesis and calculated using heteroskedasticity robust standard errors clustered at the country level. *, **, and *** represent significant level at $10 \%, 5 \%$, and $1 \%$, respectively.

\begin{tabular}{|c|c|c|c|c|c|c|c|c|c|c|c|c|}
\hline & (1) & (2) & (3) & (4) & (5) & (6) & (7) & (8) & (9) & $(10)$ & (11) & (12) \\
\hline & \multicolumn{3}{|c|}{ Dividend yield } & \multicolumn{3}{|c|}{ Dividend to cash flow } & \multicolumn{3}{|c|}{ Dividend to assets } & \multicolumn{3}{|c|}{ Dividend to sales } \\
\hline & All & $\begin{array}{c}\text { High } \\
\text { Financial } \\
\text { dependence } \\
\end{array}$ & $\begin{array}{c}\text { Low } \\
\text { Financial } \\
\text { dependence }\end{array}$ & All & $\begin{array}{c}\text { High } \\
\text { Financial } \\
\text { dependence } \\
\end{array}$ & $\begin{array}{c}\text { Low } \\
\text { Financial } \\
\text { dependence } \\
\end{array}$ & All & $\begin{array}{c}\text { High } \\
\text { Financial } \\
\text { dependence } \\
\end{array}$ & $\begin{array}{c}\text { Low } \\
\text { Financial } \\
\text { dependence } \\
\end{array}$ & All & $\begin{array}{c}\text { High } \\
\text { Financial } \\
\text { dependence } \\
\end{array}$ & $\begin{array}{c}\text { Low } \\
\text { Financial } \\
\text { dependence } \\
\end{array}$ \\
\hline Anti-self-dealing*Crisis & $\begin{array}{c}-0.000300 \\
(0.883)\end{array}$ & $\begin{array}{c}-0.00238 \\
(0.530)\end{array}$ & $\begin{array}{c}0.000535 \\
(0.825)\end{array}$ & $\begin{array}{l}-0.0254 \\
(0.300)\end{array}$ & $\begin{array}{l}-0.0383 \\
(0.302)\end{array}$ & $\begin{array}{r}-0.0215 \\
(0.418)\end{array}$ & $\begin{array}{c}-0.00391 \\
(0.140)\end{array}$ & $\begin{array}{c}-0.00598 \\
(0.106)\end{array}$ & $\begin{array}{c}-0.00254 \\
(0.420)\end{array}$ & $\begin{array}{c}-0.00490 \\
(0.220)\end{array}$ & $\begin{array}{c}-0.00599 \\
(0.156)\end{array}$ & $\begin{array}{c}-0.00418 \\
(0.335)\end{array}$ \\
\hline Crisis & $\begin{array}{c}-0.00408 \\
(0.673)\end{array}$ & $\begin{array}{c}-0.00712 \\
(0.641)\end{array}$ & $\begin{array}{l}2.06 \mathrm{e}-05 \\
(0.999)\end{array}$ & $\begin{array}{l}-0.189 * \\
(0.061)\end{array}$ & $\begin{array}{l}-0.170 \\
(0.196)\end{array}$ & $\begin{array}{l}-0.204 \\
(0.112)\end{array}$ & $\begin{array}{c}-0.00837 \\
(0.460)\end{array}$ & $\begin{array}{l}-0.0112 \\
(0.241)\end{array}$ & $\begin{array}{c}-0.00525 \\
(0.735)\end{array}$ & $\begin{array}{c}-0.0306 * * \\
(0.013)\end{array}$ & $\begin{array}{c}-0.0268 * * \\
(0.012)\end{array}$ & $\begin{array}{c}-0.0351 * \\
(0.052)\end{array}$ \\
\hline Firm-level controls & Yes & Yes & Yes & Yes & Yes & Yes & Yes & Yes & Yes & Yes & Yes & Yes \\
\hline Macro interaction controls & Yes & Yes & Yes & Yes & Yes & Yes & Yes & Yes & Yes & Yes & Yes & Yes \\
\hline Firm FE & Yes & Yes & Yes & Yes & Yes & Yes & Yes & Yes & Yes & Yes & Yes & Yes \\
\hline Year FE & Yes & Yes & Yes & Yes & Yes & Yes & Yes & Yes & Yes & Yes & Yes & Yes \\
\hline Country cluster & 36 & 35 & 35 & 36 & 35 & 35 & 36 & 35 & 35 & 36 & 35 & 35 \\
\hline Observations & 21,467 & 10,394 & 11,073 & 20,587 & 9,944 & 10,643 & 21,467 & 10,394 & 11,073 & 21,356 & 10,336 & 11,020 \\
\hline Adjusted R2 & 0.546 & 0.575 & 0.515 & 0.384 & 0.389 & 0.377 & 0.715 & 0.701 & 0.720 & 0.670 & 0.682 & 0.662 \\
\hline
\end{tabular}




\section{Table 4 Anti-self-dealing and new equity issuance in banking industry over crises}

This table reports regression results of the relation between equity issuances by banks and the Anti-self-dealing index during banking crisis episodes [t-3, $t+3]$, where $t$ is the start year of a systemic banking crisis defined in Laeven and Valencia (2012). The dependent variable is Proceeds of IPO/SEO, equals the proceeds from public equity offerings during year $t$ as a share of total assets at the close of year $t-1$. Anti-self-dealing is an index of the degree to which the law protects minority shareholders from being expropriated by managers or controlling shareholders using self-dealing transactions. Crisis equals one in the start year of a crisis and for the three years afterwards, [t, t+3], and zero otherwise, [t-3, t-1]. In columns (1) and (2), the sample includes commercial banks, bank holding companies, and other financial institutions. In columns (3) and (4), the sample only includes commercial banks. In columns (1) and (3), the dependent variable includes all IPO and SEO issuances. In columns (2) and (4), the dependent variable only includes firms that were already public three years before the crisis, i.e., SEO transactions only. Firm-level controls include: the natural logarithm of total assets, the ratio of debt to assets, and Tobin's Q, which are all lagged one year relative to the equity issuance measures, and the ratio of firm's cash flow to its assets. Macro interaction controls include interactions between Crisis and (1) GDP per capita, (2) Financial institutions development, (3) Stock market development, and (4) Private credit contraction. GDP per capita equals the natural logarithm of real GDP per capita, measured three years before the start year of the banking crisis. Financial institutions development equals the ratio of private credit by deposit money banks and other financial institutions to GDP, measured three years before the start year of the banking crisis. Stock market capitalization equals the ratio of stock market capitalization to GDP, measured three years before the start year of the banking crisis. Private credit contraction equals the average annual growth rate in bank credit to private firms between $t-3$ and $t-1$, where $t$ is the start-year of the crisis, minus the minimum annual growth rate of bank credit to private firms during the period between $\mathrm{t}$ and $\mathrm{t}+3$. P-values are reported in parenthesis and calculated using heteroskedasticity robust standard errors clustered at the country level. *,**, and $* * *$ represent significant level at $10 \%, 5 \%$, and $1 \%$, respectively.

(1)

(2)

(3)

(4)

Proceeds of IPO/SEO

\begin{tabular}{lcccc}
\cline { 2 - 4 } & \multicolumn{2}{c}{$\begin{array}{c}\text { Commercial banks, bank } \\
\text { holding companies, savings } \\
\text { banks, and credit institutions }\end{array}$} & \multicolumn{2}{c}{ Commercial banks only } \\
\cline { 2 - 5 } & Full sample & SEO only & Full sample & SEO only \\
\hline Anti-self-dealing*Crisis & $\mathbf{0 . 0 2 2 4 * * *}$ & $\mathbf{0 . 0 2 3 0 * * *}$ & $\mathbf{0 . 0 1 5 4 * * *}$ & $\mathbf{0 . 0 1 6 2 * *}$ \\
Crisis & $\mathbf{( 0 . 0 0 0 )}$ & $\mathbf{( 0 . 0 0 1 )}$ & $\mathbf{( 0 . 0 0 3 )}$ & $\mathbf{( 0 . 0 1 1 )}$ \\
Firm-level controls & -0.0321 & -0.0230 & $-0.0450^{* *}$ & $-0.0355^{* *}$ \\
Macro interaction controls & $(0.101)$ & $(0.211)$ & $(0.016)$ & $(0.020)$ \\
Firm FE & $\mathrm{Y}$ & $\mathrm{Y}$ & $\mathrm{Y}$ & $\mathrm{Y}$ \\
Year FE & $\mathrm{Y}$ & $\mathrm{Y}$ & $\mathrm{Y}$ & $\mathrm{Y}$ \\
\hline Country cluster & $\mathrm{Y}$ & $\mathrm{Y}$ & $\mathrm{Y}$ & $\mathrm{Y}$ \\
Observations & $\mathrm{Y}$ & $\mathrm{Y}$ & $\mathrm{Y}$ & $\mathrm{Y}$ \\
Adjusted R2 & 30 & 30 & 29 & 29 \\
\hline
\end{tabular}




\section{Table 5 Anti-self-dealing and firm performance over crises: Overall sample}

This table reports regression results of the relation between firm performance and the Anti-self-dealing index during banking crisis episodes [t-3, t+3], where $t$ is the start year of a systemic banking crisis as defined in Laeven and Valencia (2012). The dependent variables are EBIT to assets in column (1), Net income to assets in column (2), Cash flow to assets in column (3) and Firm employment in columns (4) and (5). EBIT to assets equals earnings before interest and taxes as a share of total assets lagged one year. Net income to assets equals net income after dividends as a share of total assets lagged one year. Cash flow to assets equals net income after dividends plus depreciation and amortization as a share of total assets lagged one year. Firm employment equals the natural logarithm of the total number of employees. Anti-self-dealing is an index of the degree to which the law protects minority shareholders from being expropriated by managers or controlling shareholders using self-dealing transactions. Crisis equals one in the start year of a crisis and for the three years afterwards, $[t, t+3]$, and zero otherwise, [t-3, t-1]. Firm-level controls include: the natural logarithm of total assets, the ratio of debt to assets, and Tobin's Q, which are all lagged one year relative to the firm performance measures, and the ratio of firm's cash flow to its assets. Macro interaction controls include interactions between Crisis and (1) GDP per capita, (2) Financial institutions development, (3) Stock market development, and (4) Private credit contraction. GDP per capita equals the natural logarithm of real GDP per capita, measured three years before the start year of the banking crisis. Financial institutions development equals the ratio of private credit by deposit money banks and other financial institutions to GDP, measured three years before the start year of the banking crisis. Stock market capitalization equals the ratio of stock market capitalization to GDP, measured three years before the start year of the banking crisis. Private credit contraction equals the average annual growth rate in bank credit to private firms between t-3 and $t-1$, where $t$ is the start-year of the crisis, minus the minimum annual growth rate of bank credit to private firms during the period between $t$ and $t+3$. In columns (4) and (5), we further split the sample of countries based on the median value of Costs of firing workers, which measures the costs due to policy and regulations of firing workers (Botero et al., 2004). P-values are reported in parenthesis and calculated using heteroskedasticity robust standard errors clustered at the country level. *, **, and ${ }^{* * *}$ represent significant level at $10 \%, 5 \%$, and $1 \%$, respectively.

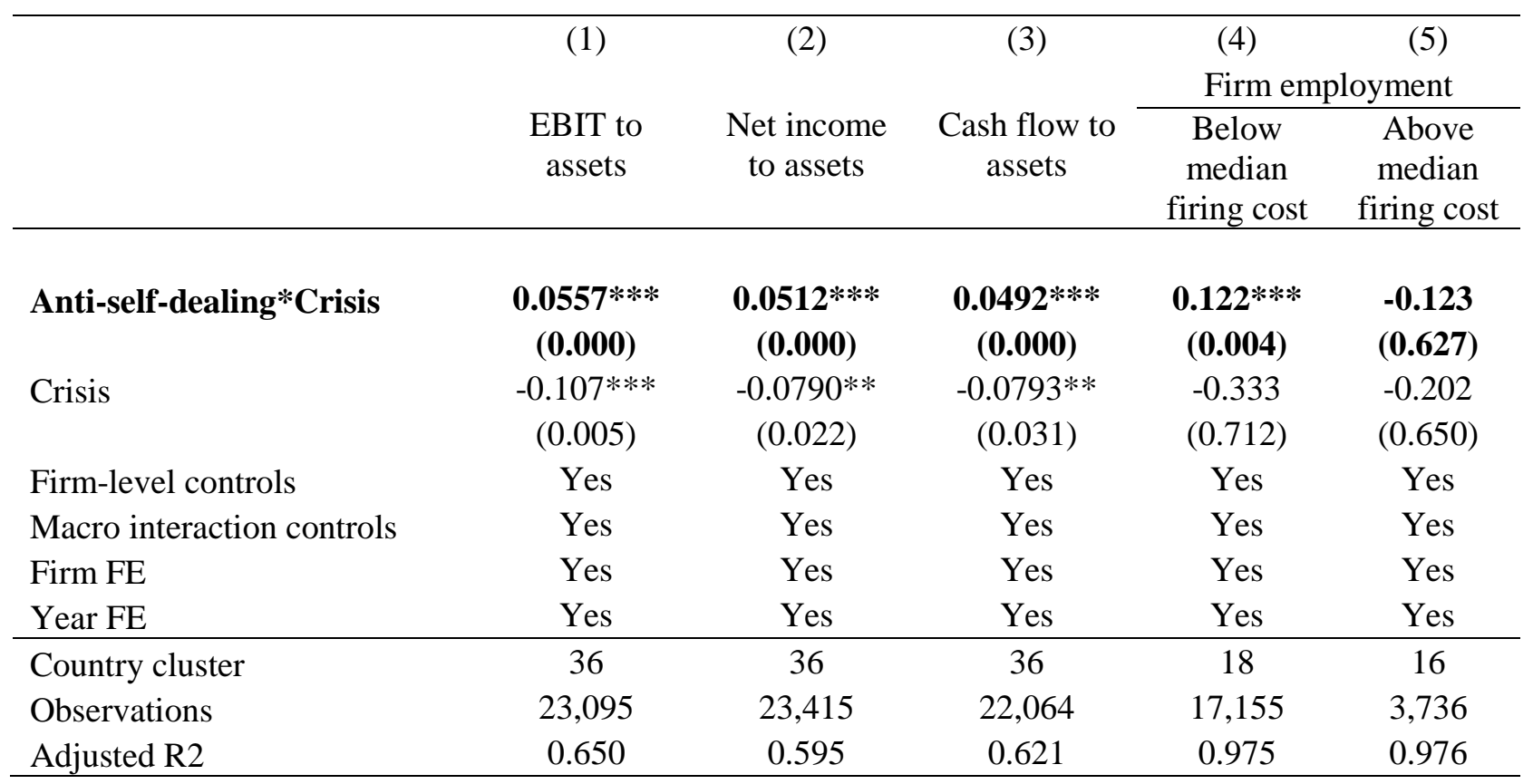



Table 6 Anti-self-dealing and firm performance over crises: horserace tests with legal protection
and institutional quality

This table reports regression results of the relation between firm performance and the Anti-self-dealing index during banking crisis episodes, while controlling for measures of legal and institutional development. Anti-self-dealing is an index of the degree to which the law protects minority shareholders from being expropriated by managers or controlling shareholders using self-dealing transactions. Crisis equals one in the start year of a crisis and for the three years afterwards, [t, $\mathrm{t}+3]$, and zero otherwise, [t-3, t-1]. In Panel A, the dependent variables are EBIT to assets, Net income to assets, and Cash flow to assets. EBIT to assets equals earnings before interest and taxes as a share of total assets lagged one year. Net income to assets equals net income after dividends as a share of total assets lagged one year. Cash flow to assets equals net income after dividends plus depreciation and amortization as a share of total assets lagged one year. In Panel B, the dependent variable is Firm employment, which equals the natural logarithm of the total number of employees. In Panel B, we further split the sample of countries based on the median value of Costs of firing workers, which measures the costs due to policy and regulations of firing workers (Botero et al., 2004). Columns with odd numbers add Rule of law*Crisis as an additional explanatory variable, whereas those with even numbers add Legal protection and institutional quality*Crisis. Rule of law measures the quality of contract enforcement, property rights, and control over crime and violence. Legal protection and institutional quality is a broad index of legal system effectiveness and institutional quality. With respect to other regressors, Firm-level controls include: the natural logarithm of total assets, the ratio of debt to assets, and Tobin's Q, which are all lagged one year relative to the firm performance measures, and the ratio of firm's cash flow to its assets. Macro interaction controls include interactions between Crisis and (1) GDP per capita, (2) Financial institutions development, (3) Stock market development, and (4) Private credit contraction. GDP per capita equals the natural logarithm of real GDP per capita, measured three years before the start year of the banking crisis. Financial institutions development equals the ratio of private credit by deposit money banks and other financial institutions to GDP, measured three years before the start year of the banking crisis. Stock market capitalization equals the ratio of stock market capitalization to GDP, measured three years before the start year of the banking crisis. Private credit contraction equals the average annual growth rate in bank credit to private firms between $t-3$ and $t-1$, where $t$ is the start-year of the crisis, minus the minimum annual growth rate of bank credit to private firms during the period between $t$ and $t+3$. P-values are reported in parenthesis and calculated using heteroskedasticity robust standard errors clustered at the country level. *, **, and $* * *$ represent significant level at $10 \%, 5 \%$, and $1 \%$, respectively. 
Panel A: Firm operating performance

\begin{tabular}{|c|c|c|c|c|c|c|}
\hline & (1) & (2) & (3) & (4) & (5) & (6) \\
\hline & \multicolumn{2}{|c|}{ EBIT to assets } & \multicolumn{2}{|c|}{ Net income to assets } & \multicolumn{2}{|c|}{ Cash flow to assets } \\
\hline & All & All & All & All & All & All \\
\hline Anti-self-dealing*Crisis & $\begin{array}{c}0.0557 * * * \\
(0.000)\end{array}$ & $\begin{array}{c}0.0538 * * * \\
(0.000)\end{array}$ & $\begin{array}{c}0.0513 * * * \\
(0.000)\end{array}$ & $\begin{array}{c}0.0506 * * * \\
(0.000)\end{array}$ & $\begin{array}{c}0.0493^{* * *} \\
(0.000)\end{array}$ & $\begin{array}{c}0.0488 * * * \\
(0.000)\end{array}$ \\
\hline Crisis & $\begin{array}{c}-0.0705^{*} \\
(0.081)\end{array}$ & $\begin{array}{l}-0.0484 \\
(0.273)\end{array}$ & $\begin{array}{c}-0.0618 * \\
(0.074)\end{array}$ & $\begin{array}{l}-0.0549 \\
(0.156)\end{array}$ & $\begin{array}{c}-0.0713^{*} \\
(0.063)\end{array}$ & $\begin{array}{l}-0.0647 \\
(0.141)\end{array}$ \\
\hline Rule of law*Crisis & $\begin{array}{l}0.0178^{* * * *} \\
(0.008)\end{array}$ & & $\begin{array}{c}0.00869 \\
(0.109)\end{array}$ & & $\begin{array}{l}0.00415 \\
(0.495)\end{array}$ & \\
\hline $\begin{array}{l}\text { Legal protection and } \\
\text { institutional quality*Crisis }\end{array}$ & & $\begin{array}{c}0.00818 * * \\
(0.011)\end{array}$ & & $\begin{array}{l}0.00344 \\
(0.178)\end{array}$ & & $\begin{array}{l}0.00216 \\
(0.462)\end{array}$ \\
\hline Firm-level controls & Yes & Yes & Yes & Yes & Yes & Yes \\
\hline Macro interaction controls & Yes & Yes & Yes & Yes & Yes & Yes \\
\hline Firm FE & Yes & Yes & Yes & Yes & Yes & Yes \\
\hline Year FE & Yes & Yes & Yes & Yes & Yes & Yes \\
\hline Country cluster & 36 & 35 & 36 & 35 & 36 & 35 \\
\hline Observations & 23,095 & 23,037 & 23,415 & 23,357 & 22,064 & 22,006 \\
\hline Adjusted R2 & 0.651 & 0.651 & 0.595 & 0.594 & 0.621 & 0.621 \\
\hline
\end{tabular}

Panel B: Firm employment

\begin{tabular}{lcccc}
\hline & $(1)$ & $(2)$ & $(3)$ & $(4)$ \\
\cline { 2 - 5 } & \multicolumn{3}{c}{ Firm employment } \\
& \multicolumn{2}{c}{ Below median } & \multicolumn{2}{c}{$\begin{array}{c}\text { Above median } \\
\text { firing cost }\end{array}$} \\
\cline { 2 - 6 } firing cost & $\mathbf{0 . 1 1 0 * * *}$ & $\mathbf{0 . 1 1 9 * * *}$ & $\mathbf{0 . 0 0 9 6 8}$ & $\mathbf{0 . 0 1 5 9}$ \\
Anti-self-dealing*Crisis & $\mathbf{( 0 . 0 0 2 )}$ & $\mathbf{( 0 . 0 0 2})$ & $\mathbf{( 0 . 9 6 4 )}$ & $\mathbf{( 0 . 9 4 4 )}$ \\
Crisis & -0.422 & -0.492 & 0.825 & $1.042^{*}$ \\
& $(0.594)$ & $(0.563)$ & $(0.118)$ & $(0.076)$ \\
Rule of law*Crisis & $-0.0837 *$ & & $0.294^{* * *}$ & \\
& $(0.050)$ & & $(0.000)$ & \\
Legal protection and institutional quality*Crisis & & -0.0282 & & $0.118^{* * *}$ \\
& & $(0.212)$ & & $(0.000)$ \\
Firm-level controls & Yes & Yes & Yes & Yes \\
Macro interaction controls & Yes & Yes & Yes & Yes \\
Firm FE & Yes & Yes & Yes & Yes \\
Year FE & Yes & Yes & Yes & Yes \\
\hline Country cluster & 18 & 18 & 16 & 16 \\
Observations & 17,155 & 17,155 & 3,736 & 3,736 \\
Adjusted R2 & 0.975 & 0.975 & 0.977 & 0.977 \\
\hline
\end{tabular}


Table 7 Anti-self-dealing and firm performance over crises: split sample by industry financial
dependence

This table reports regression results of the relation between firm performance and the Anti-self-dealing index during banking crisis episodes, while splitting firms into industries with above and below the median values of Financial dependence. Anti-self-dealing is an index of the degree to which the law protects minority shareholders from being expropriated by managers or controlling shareholders using self-dealing transactions. Crisis equals one in the start year of a crisis and for the three years afterwards, $[t, t+3]$, and zero otherwise, [t-3, t-1]. "High (Low) Financial dependence" represents the subsample of firms with Financial dependence above (below) the median value. The Financial dependence measures the extent to which firms depend on external finance and is calculated at U.S. SIC 3-digit level following the method in Rajan and Zingales (1998). Anti-self-dealing is an index of the degree to which the law protects minority shareholders from being expropriated by managers or controlling shareholders using selfdealing transactions. Crisis equals one in the start year of a crisis and for the three years afterwards, [t, $\mathrm{t}+3$ ], and zero otherwise, [t-3, t-1]. In Panel A, the dependent variables are EBIT to assets, Net income to assets, and Cash flow to assets. EBIT to assets equals earnings before interest and taxes as a share of total assets lagged one year. Net income to assets equals net income after dividends as a share of total assets lagged one year. Cash flow to assets equals net income after dividends plus depreciation and amortization as a share of total assets lagged one year. In Panel B, the dependent variable is Firm employment, which equals the natural logarithm of the total number of employees. In Panel B, we further split the sample of countries based on the median value of Costs of firing workers, which measures the costs due to policy and regulations of firing workers (Botero et al., 2004). With respect to other regressors, Firm-level controls include: the natural logarithm of total assets, the ratio of debt to assets, and Tobin's Q, which are all lagged one year relative to the firm performance measures, and the ratio of firm's cash flow to its assets. Macro interaction controls include interactions between Crisis and (1) GDP per capita, (2) Financial institutions development, (3) Stock market development, and (4) Private credit contraction. GDP per capita equals the natural logarithm of real GDP per capita, measured three years before the start year of the banking crisis. Financial institutions development equals the ratio of private credit by deposit money banks and other financial institutions to GDP, measured three years before the start year of the banking crisis. Stock market capitalization equals the ratio of stock market capitalization to GDP, measured three years before the start year of the banking crisis. Private credit contraction equals the average annual growth rate in bank credit to private firms between $\mathrm{t}-3$ and $t-1$, where $t$ is the start-year of the crisis, minus the minimum annual growth rate of bank credit to private firms during the period between $\mathrm{t}$ and $\mathrm{t}+3$. P-values are reported in parenthesis and calculated using heteroskedasticity robust standard errors clustered at the country level. *, **, and $* * *$ represent significant level at $10 \%, 5 \%$, and $1 \%$, respectively. 
Panel A: Firm operating performance

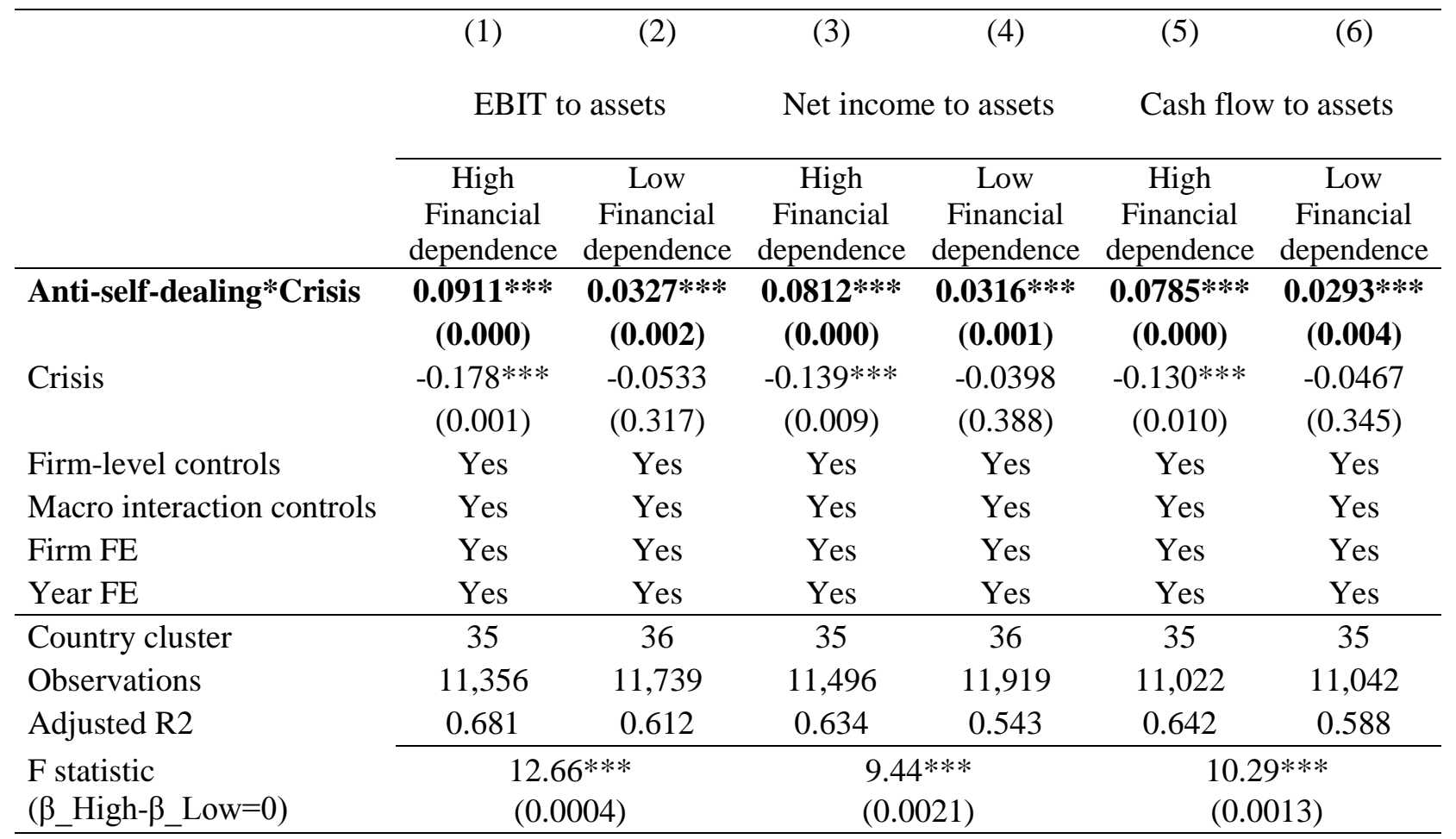

Panel B: Firm employment

(1)

(2)

(3)

(4)

Firm employment

\begin{tabular}{lcccc} 
& \multicolumn{2}{c}{ Below median firing cost } & \multicolumn{2}{c}{ Above median firing cost } \\
\cline { 2 - 5 } & $\begin{array}{c}\text { High } \\
\text { Financial } \\
\text { dependence }\end{array}$ & $\begin{array}{c}\text { Low } \\
\text { Financial } \\
\text { dependence }\end{array}$ & $\begin{array}{c}\text { High } \\
\text { Financial } \\
\text { dependence }\end{array}$ & $\begin{array}{c}\text { Low } \\
\text { Financial } \\
\text { dependence }\end{array}$ \\
\hline Anti-self-dealing*Crisis & $\mathbf{0 . 1 6 9 * * *}$ & $\mathbf{0 . 0 8 6 8 * *}$ & $\mathbf{- 0 . 3 8 3}$ & $\mathbf{0 . 1 3 0}$ \\
& $\mathbf{( 0 . 0 0 3 )}$ & $\mathbf{( 0 . 0 3 3 )}$ & $\mathbf{( 0 . 2 8 3 )}$ & $\mathbf{( 0 . 6 0 5 )}$ \\
Crisis & -1.451 & 0.159 & -0.0451 & -0.209 \\
& $(0.245)$ & $(0.822)$ & $(0.916)$ & $(0.720)$ \\
Firm-level controls & Yes & Yes & Yes & Yes \\
Macro interaction controls & Yes & Yes & Yes & Yes \\
Firm FE & Yes & Yes & Yes & Yes \\
Year FE & Yes & Yes & Yes & Yes \\
\hline Country cluster & 18 & 18 & 16 & 15 \\
Observations & 8,553 & 8,602 & 1,866 & 1,870 \\
Adjusted R2 & 0.972 & 0.976 & 0.971 & 0.982 \\
F statistic & \multicolumn{2}{c}{$4.47 * *$} \\
$(\beta$ High- $\beta$ Low 0$)$ & $(0.0345)$ & & \\
\hline
\end{tabular}




\section{Table 8 Anti-self-dealing on investment to Q sensitivity over crises}

This table reports regression results on the relation between the sensitivity of investment to Tobin's $Q$ and the Antiself-dealing index during banking crisis episodes, where $t$ is the start year of a systemic banking crisis as defined in Laeven and Valencia (2012). Anti-self-dealing is an index of the degree to which the law protects minority shareholders from being expropriated by managers or controlling shareholders using self-dealing transactions. Crisis equals one in the start year of a crisis and for the three years afterwards, [t, t+3], and zero otherwise, [t-3, $t-1]$. Tobin's $Q$ equals the $\operatorname{Ln}$ [(Market value of equity + book value of assets - book value of equity) / Book value of assets] lagged one year. In columns (1) - (3), the dependent variable is Investment 1, which equals (Capital expenditure + R\&D) / (total asset lagged one period). In columns (4) - (6), the dependent variable is Investment 2, which equals (Capital expenditure + R\&D + Selling, General and Administrative expenses) / (total assets lagged one period). For the column headings, "All" represents the full sample of firms and countries, while "High (Low) Financial dependence" represents the subsample of firms with Financial dependence above (below) the median value. The Financial dependence measures the extent to which firms depend on external finance and is calculated at U.S. SIC 3-digit level following the method in Rajan and Zingales (1998). Cash flow to assets equals net income after dividends plus depreciation and amortization as a share of total assets lagged one year. Macro interaction controls include interactions between Crisis and (1) GDP per capita, (2) Financial institutions development, (3) Stock market development, and (4) Private credit contraction. GDP per capita equals the natural logarithm of real GDP per capita, measured three years before the start year of the banking crisis. Financial institutions development equals the ratio of private credit by deposit money banks and other financial institutions to GDP, measured three years before the start year of the banking crisis. Stock market capitalization equals the ratio of stock market capitalization to GDP, measured three years before the start year of the banking crisis. Private credit contraction equals the average annual growth rate in bank credit to private firms between $t-3$ and $t-1$, where $t$ is the start-year of the crisis, minus the minimum annual growth rate of bank credit to private firms during the period between $t$ and $t+3$. P-values are reported in parenthesis and calculated using heteroskedasticity robust standard errors clustered at the country level. $*$, **, and $* * *$ represent significant level at $10 \%, 5 \%$, and $1 \%$, respectively.

(1)

(2)

Investment 1

All

\begin{tabular}{|c|c|c|c|c|c|c|}
\hline & All & $\begin{array}{c}\text { High } \\
\text { Financial } \\
\text { dependence }\end{array}$ & $\begin{array}{c}\text { Low } \\
\text { Financial } \\
\text { dependence }\end{array}$ & All & $\begin{array}{c}\text { High } \\
\text { Financial } \\
\text { dependence }\end{array}$ & $\begin{array}{c}\text { Low } \\
\text { Financial } \\
\text { dependence }\end{array}$ \\
\hline \multirow[t]{2}{*}{$\begin{array}{l}\text { Anti-self-dealing*Tobin's } \\
Q^{*} \text { Crisis }\end{array}$} & $0.0310 * *$ & $0.0452 * * *$ & 0.0219 & $0.0816 * * *$ & $0.121 * * *$ & 0.0369 \\
\hline & $(0.013)$ & $(0.001)$ & $(0.210)$ & $(0.001)$ & $(0.000)$ & $(0.214)$ \\
\hline Tobin's Q*Crisis & $\begin{array}{c}-0.0190 * * \\
(0.020)\end{array}$ & $\begin{array}{c}-0.0323^{* * *} \\
(0.001)\end{array}$ & $\begin{array}{c}-0.00804 \\
(0.388)\end{array}$ & $\begin{array}{c}-0.0708^{* * *} \\
\quad(0.000)\end{array}$ & $\begin{array}{c}-0.0979 * * * \\
(0.000)\end{array}$ & $\begin{array}{c}-0.0422 * * \\
(0.027)\end{array}$ \\
\hline Anti-self-dealing*Tobin's Q & $\begin{array}{c}0.000529 \\
(0.970)\end{array}$ & $\begin{array}{c}-0.0230 \\
(0.150)\end{array}$ & $\begin{array}{l}0.0185 \\
(0.516)\end{array}$ & $\begin{array}{c}0.0635^{*} \\
(0.088)\end{array}$ & $\begin{array}{l}0.0524 \\
(0.346)\end{array}$ & $\begin{array}{c}0.0695 * * * \\
(0.003)\end{array}$ \\
\hline Anti-self-dealing*Crisis & $\begin{array}{c}-0.00772 \\
(0.419)\end{array}$ & $\begin{array}{l}-0.0143 \\
(0.156)\end{array}$ & $\begin{array}{c}-0.00489 \\
(0.728)\end{array}$ & $\begin{array}{c}-0.0272^{* *} \\
(0.042)\end{array}$ & $\begin{array}{l}-0.0195 \\
(0.340)\end{array}$ & $\begin{array}{c}-0.0351^{* *} \\
(0.043)\end{array}$ \\
\hline Crisis & $\begin{array}{l}-0.0123 \\
(0.760)\end{array}$ & $\begin{array}{r}-0.0132 \\
(0.732)\end{array}$ & $\begin{array}{l}-0.0124 \\
(0.754)\end{array}$ & $\begin{array}{l}0.107^{*} \\
(0.059)\end{array}$ & $\begin{array}{l}0.0836 \\
(0.170)\end{array}$ & $\begin{array}{l}0.123^{*} \\
(0.067)\end{array}$ \\
\hline Tobin's Q & $\begin{array}{c}0.0382 * * * \\
(0.001)\end{array}$ & $\begin{array}{l}0.0611^{* * *} \\
(0.000)\end{array}$ & $\begin{array}{l}0.0162 \\
(0.263)\end{array}$ & $\begin{array}{l}0.0716^{* * *} \\
(0.005)\end{array}$ & $\begin{array}{l}0.0967 * * * \\
(0.008)\end{array}$ & $\begin{array}{c}0.0450 * * \\
(0.029)\end{array}$ \\
\hline Cash flow to assets & $\begin{array}{c}0.0630 * \\
(0.080)\end{array}$ & $\begin{array}{l}0.0491 \\
(0.194)\end{array}$ & $\begin{array}{c}0.0774^{* *} \\
(0.032)\end{array}$ & $\begin{array}{c}0.147^{* *} \\
(0.033)\end{array}$ & $\begin{array}{l}0.0761 \\
(0.418)\end{array}$ & $\begin{array}{c}0.233^{* * *} \\
(0.000)\end{array}$ \\
\hline Macro interaction controls & Yes & Yes & Yes & Yes & Yes & Yes \\
\hline Firm FE & Yes & Yes & Yes & Yes & Yes & Yes \\
\hline
\end{tabular}

(3)
(4)

Low

Financial Financial

dependence dependence
(5)

(6) 


\begin{tabular}{|c|c|c|c|c|c|c|}
\hline Year FE & Yes & Yes & Yes & Yes & Yes & Yes \\
\hline Country cluster & 36 & 36 & 35 & 34 & 31 & 33 \\
\hline Observations & 18,318 & 9,098 & 9,220 & 14,352 & 7,131 & 7,221 \\
\hline Adjusted R2 & 0.545 & 0.578 & 0.490 & 0.796 & 0.784 & 0.810 \\
\hline $\begin{array}{l}\text { F statistic } \\
\left(\beta \_ \text {High- } \beta \_ \text {Low }=0\right)\end{array}$ & & \multicolumn{2}{|c|}{$\begin{array}{c}1.86 \\
(0.1726)\end{array}$} & & \multicolumn{2}{|c|}{$\begin{array}{l}6.98 * * * \\
(0.0082)\end{array}$} \\
\hline
\end{tabular}




\section{Appendix}

\section{Table A.1 Variable definitions and data sources}

\begin{tabular}{|c|c|c|}
\hline Variable & Definition & Source \\
\hline $\begin{array}{l}\text { Anti-self-dealing } \\
\text { index }\end{array}$ & $\begin{array}{l}\text { Legal protection measure } \\
\text { Djankov et al. (2008) index of the degree to which the law protects minority } \\
\text { shareholders from being expropriated by managers or controlling shareholders using } \\
\text { self-dealing transactions. Equals: Average of approvals of disinterested shareholders, } \\
\text { ex-ante disclosure (disclosure by buyer and main owner of the seller, and independent } \\
\text { review by a professional third party), and ex-post disclosure (periodic filings and ease of } \\
\text { proving wrongdoing). }\end{array}$ & Djankov et al. (2008) \\
\hline Crisis & $\begin{array}{l}\text { Equals one in the start year of a crisis, period } t \text {, and for the three years afterwards, }[t \text {, } \\
t+3] \text {. }\end{array}$ & $\begin{array}{l}\text { Laeven and Valencia } \\
\text { (2012) }\end{array}$ \\
\hline
\end{tabular}

\section{Firm-level data}

Equity issuance

Proceeds of IPO/SEO

\section{$(\Delta \mathrm{Com}$} year

Total proceeds from initial public or seasoned equity offerings / Total assets lagged one year.

Dividend yield

Dividend to cash flow

Dividend to assets

Dividend to sales

EBIT to assets

Net income to assets

Cash flow to assets

Firm employment
Total cash dividends / Market capitalization lagged one year (using the closing stock price at firms' fiscal year end).

Total cash dividends / Cash flow.

Total cash dividends / Total assets lagged one year.

Total cash dividends / Net sales.

Earnings before interest and tax (EBIT)/ Total assets lagged one year.

(Net income after dividends) / Total assets lagged one year.

(Net Income after dividends + Depreciations \& Amortizations) / Total assets lagged one year.

Natural logarithm of the total number of employees.

\section{Worldscope}

SDC Global Equity Issuance

\section{Worldscope}

Worldscope

Worldscope

Worldscope

Worldscope

Worldscope

Worldscope

Worldscope 


\begin{tabular}{llr} 
Investment 1 & (Capital expenditure + R\&D ) / Total assets lagged one year. & Worldscope \\
Investment 2 & (Capital expenditure + R\&D + Selling, General and Administrative expenses) / Total & Worldscope \\
Firm Size & assets lagged one year & Worldscope \\
Leverage & Natural logarithm of total assets & Worldscope \\
Tobin's Q & $\begin{array}{l}\text { Total debt / Total assets } \\
\text { Ln [(Market value of equity + book value of assets - book value of equity) / Book value } \\
\text { of assets] }\end{array}$ & Worldscope \\
\hline
\end{tabular}

$\begin{array}{ll}\text { Industry Characteristics } & \\ & \begin{array}{l}\text { Equals to (Capital expenditures - Cash flow from operations) / Capital expenditures, } \\ \text { where both capital expenditures and cash flow are summed over a ten-year window for }\end{array} \\ \text { Financial dependence } & \begin{array}{l}\text { Cach U.S. firm. We then take the median value of the ratio among firms with the same the } \\ \text { three-digit U.S. SIC code as the financial dependence index for that particular industry Compustat, } \\ \text { for the crisis country. }\end{array} \\ \text { Zingales (1998) }\end{array}$

\section{Other Country Characteristics}

GDP per capita

Stock market development

Natural logarithm of real GDP per capita, measured three years before the start year of the banking crisis.

The ratio of stock market capitalization to GDP, measured three years before the start year of the banking crisis.

Financial institutions development

Private credit contraction

Rule of law
The ratio of private credit by deposit money banks and other financial institutions to GDP, measured three years before the start year of the banking crisis.

The average annual growth rate in bank credit to private firms between $t-3$ and $t-1$, where $t$ is the start-year of the crisis, minus the minimum annual growth rate of bank credit to private firms during the period between $t$ and $t+3$.

The extent to which agents have confidence in and abide by the rules of society, and in particular the quality of contract enforcement, property rights, the police, and the courts, as well as the likelihood of crime and violence.
World Development Indicators, the World Bank

Čihák et al. (2013)

Calculated by the authors; World development indicators (WDI), World Bank World Governance Indicators (WGI); Kaufmann et al. (2013) 
Legal protection and institutional quality

Cost of firing workers
This is an index of legal system effectiveness and institutional quality that is constructed as the first principal component of the eight variables, namely Creditor rights index (Djankov et al., 2007), Protection of property rights (Fraser Institute), and six individual components of WGI (i.e. rule of law, voice and accountability, political stability, government effectiveness, regulatory quality and control of corruption) constructed by Kaufmann et al. (2013).

It measures the cost of firing 20 percent of the firm's workers, and equals the ratio of the new wage bill to the old one. The new wage bill is calculated as the normal wage of the remaining workers plus the cost of firing workers. Specifically, the cost of firing a worker is defined as the sum of the notice period, severance pay, and any mandatory penalties established by law or mandatory collective agreements for a worker with three years of tenure with the firm. If dismissal is illegal, the cost of firing is set as the annual wage.
Calculated by the authors based on Economic Freedom Worlds (EFW) datasets, Djankov et al., (2007); Fraser Institute, Kaufmann et al. (2013)

Botero et al. (2004) 
Table A.2 List of country characteristics

The variables are defined in Table A.1.

\begin{tabular}{|c|c|c|c|c|c|c|c|c|c|c|c|}
\hline & Country name & $\begin{array}{l}\text { Country } \\
\text { code }\end{array}$ & $\begin{array}{l}\text { Start year } \\
\text { of crises }\end{array}$ & $\begin{array}{c}\text { Anti- } \\
\text { self- } \\
\text { dealing } \\
\text { index }\end{array}$ & $\begin{array}{l}\text { GDP } \\
\text { per } \\
\text { capita }\end{array}$ & $\begin{array}{c}\text { Financial } \\
\text { institutions } \\
\text { development }\end{array}$ & $\begin{array}{l}\text { Stock market } \\
\text { development }\end{array}$ & $\begin{array}{c}\text { Private } \\
\text { credit } \\
\text { contraction }\end{array}$ & $\begin{array}{l}\text { Rule } \\
\text { of law }\end{array}$ & $\begin{array}{c}\text { Legal } \\
\text { protection and } \\
\text { institutional } \\
\text { quality } \\
\end{array}$ & $\begin{array}{c}\text { Cost of } \\
\text { firing } \\
\text { workers }\end{array}$ \\
\hline 1 & Argentina & ARG & 1995, 2001 & 0.342 & 8.295 & 0.129 & 0.082 & 0.501 & 0.037 & -1.291 & 0.273 \\
\hline 2 & Austria & AUT & 2008 & 0.213 & 10.520 & 1.082 & 0.346 & 0.077 & 1.863 & 2.928 & 0.217 \\
\hline 3 & Belgium & BEL & 2008 & 0.544 & 10.492 & 0.715 & 0.751 & 0.126 & 1.240 & 2.035 & 0.160 \\
\hline 4 & Switzerland & $\mathrm{CHE}$ & 2008 & 0.267 & 10.854 & 1.543 & 2.290 & 0.090 & 1.899 & 3.150 & 0.165 \\
\hline 5 & China, Mainland & $\mathrm{CHN}$ & 1998 & 0.763 & 6.657 & 0.741 & 0.061 & 0.139 & -0.431 & -2.890 & 0.599 \\
\hline 6 & Colombia & COL & 1998 & 0.573 & 8.058 & 0.306 & 0.169 & 0.372 & -0.892 & -3.287 & 0.549 \\
\hline 7 & Germany & DEU & 2008 & 0.282 & 10.421 & 1.118 & 0.437 & 0.019 & 1.656 & 2.727 & 0.485 \\
\hline 8 & Denmark & DNK & 2008 & 0.463 & 10.769 & 1.616 & 0.642 & 0.157 & 1.945 & 3.479 & 0.505 \\
\hline 9 & Spain & ESP & 2008 & 0.374 & 10.162 & 1.299 & 0.840 & 0.262 & 1.097 & 1.449 & 0.358 \\
\hline 10 & Finland & FIN & 1991 & 0.457 & 10.198 & 0.702 & 0.260 & 0.282 & 1.876 & 2.901 & 0.531 \\
\hline 11 & France & FRA & 2008 & 0.379 & 10.429 & 0.902 & 0.779 & 0.099 & 1.400 & 1.996 & 0.433 \\
\hline 12 & United Kingdom & GBR & 2007 & 0.950 & 10.532 & 1.424 & 1.267 & 0.135 & 1.623 & 2.636 & 0.487 \\
\hline 13 & Greece & GRC & 2008 & 0.217 & 9.981 & 0.732 & 0.563 & 0.214 & 0.776 & 0.499 & 0.566 \\
\hline 14 & Hungary & HUN & 2008 & 0.181 & 9.300 & 0.476 & 0.283 & 0.220 & 0.826 & 0.992 & 0.352 \\
\hline 15 & Indonesia & IDN & 1997 & 0.653 & 6.964 & 0.473 & 0.224 & 0.780 & -0.366 & -3.030 & 0.685 \\
\hline 16 & India & IND & 1993 & 0.579 & 5.999 & 0.241 & 0.097 & 0.018 & 0.259 & -2.343 & 0.623 \\
\hline 17 & Ireland & IRL & 2008 & 0.789 & 10.793 & 1.413 & 0.564 & 0.346 & 1.580 & 2.804 & 0.546 \\
\hline 18 & Italy & ITA & 2008 & 0.421 & 10.325 & 0.855 & 0.446 & 0.084 & 0.468 & 0.252 & 0.452 \\
\hline 19 & Japan & JPN & 1997 & 0.499 & 10.387 & 1.997 & 0.721 & 0.038 & 1.318 & 1.081 & 0.080 \\
\hline 20 & Kazakhstan & KAZ & 2008 & 0.483 & 8.235 & 0.276 & 0.126 & 0.694 & -0.824 & -3.152 & 0.605 \\
\hline 21 & Korea & KOR & 1997 & 0.469 & 9.327 & 0.550 & 0.395 & 0.101 & 0.752 & -0.503 & 0.617 \\
\hline 22 & Luxembourg & LUX & 2008 & 0.283 & 11.301 & 1.127 & 1.351 & 0.368 & 1.825 & . & . \\
\hline 23 & Latvia & LVA & 2008 & 0.319 & 8.877 & 0.553 & 0.128 & 0.595 & 0.590 & 0.223 & 0.527 \\
\hline 24 & Mexico & MEX & 1994 & 0.172 & 8.808 & 0.172 & 0.198 & 0.581 & -0.759 & -2.288 & 0.426 \\
\hline 25 & Malaysia & MYS & 1997 & 0.950 & 8.309 & 1.010 & 2.792 & 0.262 & 0.607 & -0.285 & 0.195 \\
\hline 26 & Nigeria & NGA & 2009 & 0.433 & 6.742 & 0.121 & 0.184 & 0.773 & -1.081 & -4.434 & 0.036 \\
\hline 27 & Netherlands & NLD & 2008 & 0.203 & 10.574 & 1.592 & 0.894 & 0.160 & 1.747 & 3.106 & 0.688 \\
\hline
\end{tabular}




\begin{tabular}{|c|c|c|c|c|c|c|c|c|c|c|c|}
\hline 28 & Norway & NOR & 1991 & 0.421 & 10.686 & 0.782 & 0.193 & 0.113 & 1.889 & 3.050 & 0.527 \\
\hline 29 & Philippines & PHL & 1997 & 0.215 & 6.878 & 0.323 & 0.774 & 0.468 & -0.005 & -1.994 & 0.575 \\
\hline 30 & Portugal & PRT & 2008 & 0.444 & 9.813 & 1.358 & 0.357 & 0.110 & 1.198 & 1.607 & 0.615 \\
\hline 31 & Russia & RUS & 2008 & 0.440 & 8.582 & 0.233 & 0.539 & 0.425 & -0.905 & -3.605 & 0.609 \\
\hline 32 & Slovak Rep & SVK & 1998 & 0.290 & 8.938 & 0.358 & 0.049 & 0.474 & 0.153 & -0.650 & 0.651 \\
\hline 33 & Sweden & SWE & 2008 & 0.333 & 10.622 & 1.026 & 1.044 & 0.087 & 1.776 & 3.020 & 0.529 \\
\hline 34 & Thailand & THA & 1997 & 0.813 & 7.652 & 1.132 & 0.921 & 0.398 & 0.541 & -1.308 & 0.632 \\
\hline 35 & Turkey & TUR & 2000 & 0.429 & 8.710 & 0.191 & 0.180 & 0.514 & -0.171 & -2.426 & 0.414 \\
\hline \multirow[t]{2}{*}{36} & Ukraine & UKR & 2008 & 0.081 & 7.511 & 0.259 & 0.215 & 0.734 & -0.790 & -3.132 & 0.570 \\
\hline & Average & & 2002.946 & 0.437 & 9.242 & 0.801 & 0.588 & 0.300 & 0.687 & 0.095 & 0.465 \\
\hline
\end{tabular}




\section{Table A.3 The impact of shareholder protection laws on the size of crises shocks}

This table reports cross-country regression results of Private credit contraction against the Anti-self-dealing index and other country traits. Private credit contraction equals the average annual growth rate in bank credit to private firms between $t-3$ and $t-1$, where $t$ is the start-year of the crisis, minus the minimum annual growth rate of bank credit to private firms during the period between $t$ and $t+3$. Anti-self-dealing is an index of the degree to which the law protects minority shareholders from being expropriated by managers or controlling shareholders using self-dealing transactions. Rule of law measures the quality of contract enforcement, property rights, and control over crime and violence. Legal protection and institutional quality is a broad index of legal system effectiveness and institutional quality. GDP per capita equals the natural logarithm of real GDP per capita, measured three years before the start year of the banking crisis. Financial institutions development equals the ratio of private credit by deposit money banks and other financial institutions to GDP, measured three years before the start year of the banking crisis. Stock market capitalization equals the ratio of stock market capitalization to GDP, measured three years before the start year of the banking crisis. P-values are reported in parenthesis and calculated using heteroskedasticity robust standard errors. *, **, and *** represent significant level at $10 \%, 5 \%$, and $1 \%$, respectively.

\section{(1)}

(3) (4)

Private credit contraction

\section{Anti-self-dealing}

Rule of law

Legal protection and institutional quality

GDP per capita

$\begin{array}{ccc}\mathbf{- 0 . 1 0 8} & \mathbf{- 0 . 1 2 4} & \mathbf{- 0 . 1 5 8} \\ \mathbf{( 0 . 4 9 7 )} & \mathbf{( 0 . 3 1 2 )} & \mathbf{( 0 . 2 1 9 )} \\ & -0.166^{* * *} & \\ & (0.000) & \\ & & -0.0662^{* * *} \\ & & (0.000)\end{array}$

Financial institutions development

Stock market development

Constant

$0.348 * * *$

$0.468 * * *$

(0.000)

36

36

$-0.0190$

0.493

Observations

$(0.022)$

Adjusted R2

0.474 